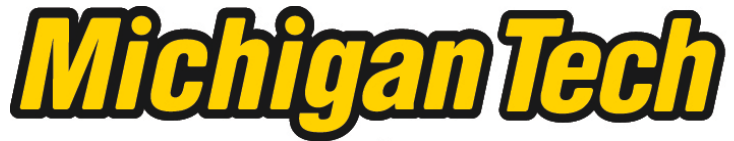 \\ Michigan Technological University Create the Future Digital Commons @ Michigan Tech
}

\section{Effect of implementing project-based education in high school physics : file folder bridge engineering}

Amy P. Muzzarelli

Michigan Technological University

Follow this and additional works at: https://digitalcommons.mtu.edu/etds

Part of the Science and Mathematics Education Commons

Copyright 2007 Amy P. Muzzarelli

\section{Recommended Citation}

Muzzarelli, Amy P., "Effect of implementing project-based education in high school physics : file folder bridge engineering ", Master's report, Michigan Technological University, 2007.

https://doi.org/10.37099/mtu.dc.etds/528

Follow this and additional works at: https://digitalcommons.mtu.edu/etds

8 Part of the Science and Mathematics Education Commons 


\title{
The Effect of Implementing Project-based Education in High School Physics: File Folder Bridge Engineering
}

\author{
By \\ Amy P. Muzzarelli
}

\begin{abstract}
A Research Report
Submitted in partial fulfillment of the requirements

for the degree of

MASTER OF APPLIED SCIENCE EDUCATION
\end{abstract}

Michigan Technological University

August 2007

Copyright (C) Amy Muzzarelli 2007 
(This page deliberately blank) 
This research report, "The Effect of Implementing Project-based Education in High School Physics: File Folder Bridge Engineering", is hereby approved in partial fulfillment of the requirements for the degree of MASTER OF APPLIED SCIENCE EDUCATION at MICHIGAN TECHNOLOGICAL UNIVERSITY.

DEPARTMENT or PROGRAM:

Department of Education

APPROVED BY:

Thesis Advisor

Typewritten Name $\quad$ Dr. William L. Yarroch

Department Chair

Typewritten Name $\quad \underline{\text { Dr. Bradley H. Baltensperger }}$

Date

August 2, 2007 
(This page deliberately blank) 


\section{Acknowledgements}

First and foremost, I would like to thank my dearest husband, Ry, and children for being so supportive and understanding in the process of completing my Masters. I couldn't have done it without you! I am very lucky to have such a support system around me.

Secondly, I would like to thank Dr. Yarroch for all of his help in editing and making this paper complete. I appreciate your help, patience, and thorough critiques in this process.

Lastly, I would like to thank my students for being cooperative and hard-working in this journey. I appreciate the willingness to try something new and give honest feedback to help build meaningful curriculum. 
(This page deliberately blank) 


\section{Table of Contents}

\begin{tabular}{|c|c|}
\hline Acknowledgements & $\mathrm{i}$ \\
\hline Table of Contents & iii \\
\hline List of Tables & vii \\
\hline Abstract & ix \\
\hline Chapter 1 -Statement of Topic & 1 \\
\hline Area of Focus & 1 \\
\hline Rationale & 2 \\
\hline Michigan HSCEs Addressed & 3 \\
\hline How HSCEs Were Met and Measured & 6 \\
\hline Research Questions & 7 \\
\hline Variable Definition & 7 \\
\hline Measurement Tools & $\overline{88}$ \\
\hline Hypothesized Results & 8 \\
\hline Data Collection & 9 \\
\hline Possible Effect of This Research & 9 \\
\hline Resources Available & 9 \\
\hline Timeline & 10 \\
\hline Chapter 2-Literature Review & 13 \\
\hline Traditional Approaches to Learning & 13 \\
\hline Project-Based Learning & 14 \\
\hline Designing and Building File Folder Bridges & 16 \\
\hline Project-Based Learning and Attitude & 19 \\
\hline Portfolio Assessment and Project-Based Learning & 20 \\
\hline Reliability and Validity of Portfolio Assessments & 21 \\
\hline Chapter 3-Procedures & 23 \\
\hline The Subjects & 23 \\
\hline The Teacher & 25 \\
\hline Instructional Unit & 26 \\
\hline Need Statement Overview & 30 \\
\hline
\end{tabular}




\section{Table of Contents (continued)}

\begin{tabular}{|ll}
\hline Overview of Unit Objectives & 31
\end{tabular}

\begin{tabular}{|ll}
\hline Michigan High School Content Expectations (HSCEs) & 33
\end{tabular}

\begin{tabular}{|ll}
\hline Portfolio Design and Development & 37 \\
\hline
\end{tabular}

Survey Development 38

Student Questionnaire 42

\begin{tabular}{|lr|}
\hline Procedures & 44 \\
\hline
\end{tabular}

\begin{tabular}{|lc}
\hline Bridge Testing & 46
\end{tabular}

\begin{tabular}{|ll}
\hline Data Collection Method & 46
\end{tabular}

$\begin{array}{ll}\text { Data Analysis } & 47\end{array}$

$\begin{array}{lr}\text { Chapter 4-Data Analysis } & 49\end{array}$

Pre-survey Data for Assessing Attitude Towards Science and

Related Careers

Pre-survey Data for Learning and Assessment Preferences $\quad 50$

Pre- and Post-survey Comparison of Data for Attitude

Toward Science and Related Careers $\quad 50$

Pre- and Post-survey Comparison of Data for Learning and

Assessment Preference Data

\begin{tabular}{|lr|}
\hline Questionnaire Results & 57 \\
\hline
\end{tabular}

\begin{tabular}{|lr}
\hline \hline Portfolio Assessment & 59 \\
\hline
\end{tabular}

\begin{tabular}{|ll}
\hline Grading & 61 \\
\hline
\end{tabular}

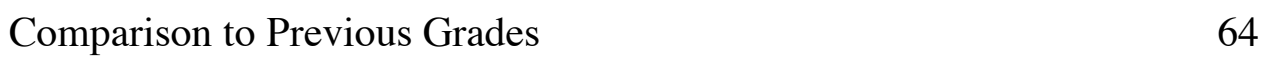

Chapter 5-Discussion $\quad 65$

Analysis of Findings on Student Attitude Toward Science 65

\begin{tabular}{|lc|}
\hline \hline Analysis of Findings on Student Preferences & 67 \\
\hline
\end{tabular}

Will students be able to demonstrate understanding using a portfolio? 68

$\begin{array}{lr}\text { Student Feedback Questionnaire } & 69\end{array}$

$\begin{array}{ll}\text { Chapter 6-Conclusion and Implications } & 71\end{array}$

\begin{tabular}{ll} 
Conclusion on Student Attitude Towards Science & 71 \\
\hline
\end{tabular}

\begin{tabular}{ll}
\hline Conclusions on Student Attitudes Towards Engineering & 72 \\
\hline
\end{tabular}

\begin{tabular}{ll}
\hline Conclusions on Learning Preferences & 72 \\
\hline
\end{tabular}




\section{Table of Contents (continued)}

\begin{tabular}{|lr|}
\hline Conclusions on Portfolio Assessments & 73 \\
\hline Changes for Future Research & 75 \\
\hline Implications for Research & 76 \\
\hline References & 77 \\
\hline \hline Appendix A-Portfolio Rubric & 83 \\
\hline Appendix B-Student Survey & 91 \\
\hline Appendix C-Student Questionnaire & 95 \\
\hline \hline Appendix D-Lesson Plans & 99 \\
\hline Appendix E-Raw Data & 129 \\
\hline
\end{tabular}


(This page deliberately blank) 


\section{List of Tables}

Table 1-Michigan High School Content Expectations Addressed

Table 2-General Timeline

Table 3-Lesson Sequence and Objectives

Table 4-Michigan High School Content Expectations (HSCEs)

Table 5-Attitude and Learning Preferences Student Survey

Table 6-Bridge Project Questionnaire for Detailed Student Feedback 43

Table 7-General Timeline for Research Procedures

Table 8-Pre- and Post-survey Change in the Attitude of Students

Table 9-Pre- and Post-survey Change in Preference of Students

Table 10-Mean and Standard Deviation from Student Questionnaire

Results from Project Ranking

Table 11-Student Questionnaire Feedback

Table 12-HSCEs Assessed in Grading Rubric

Table 13-Student Grades

Table 14-Traditional Chapter Test Mean Scores 
(This page deliberately blank) 


\begin{abstract}
Project-based education and portfolio assessments are at the forefront of educational research. This research follows the implementation of a project-based unit in a high school physics class. Students played the role of an engineering firm who designed, built and tested file folder bridges. The purpose was to determine if projectbased learning could improve student attitude toward science and related careers like engineering. Teams of students presented their work in a portfolio for a final assessment of the process of designing, building and testing their bridges.
\end{abstract}


(This page deliberately blank) 


\section{Chapter 1-Statement of Problem}

\section{Area of Focus Statement}

When I began working at Elk Rapids High School (ERHS), I knew I would be taking on Physics as one of my teaching assignments. Being a Biology major in my undergraduate schooling, I knew teaching Physics would be a challenge. I immediately began my graduate studies in Applied Science Education in order to beef up in the sciences I did not get a lot of experience in during my undergraduate work. During the first course I took, Civil Engineering was emphasized through building file folder bridges and with West Point Bridge Builder (WPBB) (Ressler, 2002). I found engineering would be best applied in the honors physics course so students would be exposed to this career possibility.

Building file folder bridges would show students how forces are applied in structural engineering. The Design-Bid-Build concepts were applied during the project. To set the inquiry stage, a mock city council accepted bids for a bridge that needed to be replaced. Students worked in teams of two and three and designed a bridge that met the city's needs. The bridge that was accepted by the council (me) was the most cost effective, light-weight, and efficient.

To visualize how forces were distributed in each member of their designed bridge before it was built, the computer program, West Point Bridge Builder (Ressler, 2002), was used. WPBB is a free computer program that allows one to design a bridge and test how well it will stand up when a computer-generated semi truck drives over the bridge. Students are able to see where the weakest, as well as the strongest part of the bridge's design is in with this program. The application of forces, equilibrium, and trigonometric 
functions using this program helped engage students in the learning process while meeting several of the Michigan High School Content Expectations (HSCEs).

\section{Rationale}

There were four major learning goals that would be focused on. The physics HSCEs would be met in the context of the distribution of forces through the bridge. Students' attitudes towards physics would improve. In the past students have expressed their dislike for the subject and that they don't need physics. One goal from this research is to improve student attitudes by implementing PBL. The goal is to show the students the application of physics in the structure of the bridge.

Students will also be exposed to the process of engineering. It is the intent that the students will gain some insight as to the career field of engineering and possibly increase the interest in engineering as a career choice.

Because the other courses I teach are also taught by other instructors, we are required to use common assessments and lesson plans when teaching. I am the only instructor that teaches honors physics. This allows me more diversity in my lesson plans and build in project-based education.

Lastly, I wanted to expose students to a cooperative team assignment and assessment tool. The work that they were doing had to be completed through teamwork. In the science courses at ERHS, students do not get much exposure to cooperative learning and assessments. 


\section{Michigan High School Content Expectations Addressed}

The codes for the HSCEs were developed by the Michigan Department of Education. For example, P3.1A represents the code for physics content (P), third standard statement (3), and content statement (1). The capitol letter at the end indicates the content as essential knowledge or skills. Other content expectations have lower-cased letters that designate the content statement as either a prerequisite with a lower-case $p$, core topic with a lower-cased $\mathrm{x}$, or required with a lower-case $\mathrm{r}$. The Michigan HSCEs (2006) can be found on the Michigan Department of Education website. A description of each HSCE addressed in this project is listed in Table 1. 
Table 1. Michigan High School Content Expectations Addressed

Identification Code

Statement

Science P1.1A Generate new questions that can be investigated in the lab or field.

P1.1B Evaluate the uncertainties or validity of scientific conclusions using an understanding of sources of measurement error, the challenges of controlling variables, accuracy of data analysis, logic of argument, logic of experimental design, and/or the dependence on underlying assumptions.

P1.1C Conduct scientific investigations using appropriate tools and techniques (e.g., selecting an instrument that measures the desired quantity-length, volume, weight, time interval, temperature-with the appropriate level of precision).

P1.1E Predict what would happen if the variables, methods, or timing of an investigation were changed.

P1.1g Based on empirical evidence, explain and critique the reasoning used to draw a scientific conclusion or explanation.

P1.1h Design and conduct a systematic scientific investigation that tests a hypothesis. Draw conclusions from data presented in charts or tables.

P3.1A Identify the forces(s) acting between objects in "direct contact" or at a distance.

P3.2A Identify the magnitude and direction of everyday forces (e.g., wind, tension in ropes, pushes and pulls, weight). 
Table 1. (continued)

P3.2C Calculate the net force acting on an object.

P3.4C Solve problems involving force, mass, and acceleration in linear motion (Newton's second law).

Math G1.3.1 Define the sine, cosine, and tangent of acute angles in a right triangle as ratios of sides. Solve problems about angles, side lengths, or areas using trigonometric ratios in right triangles. 


\section{How High School Content Expectations Were Met and Measured.}

The students were given a particular situation in which a township must replace a bridge that was damaged. Before constructing their model bridge, students assessed the need in order to determine what size bridge members would give them the lightest yet still structurally sound bridge (P1.1A). A bridge member is one structural beam in the truss of the bridge. Students constructed tension and compression members of various lengths and width. They hypothesized how the different sized members performed when they were tested to failure. The mass of the sand was measured using a scale, converted to a force $(\mathrm{P} 3.2 \mathrm{~A})$, and plotted on a graph $(\mathrm{P} 1.1 \mathrm{C})$. From this data, the teams needed to determine the most efficient sized members to use for their bridges $(\mathrm{P} 1.1 \mathrm{~h})$. When the bridges were tested, a bucket was placed on the bridges at 4 different nodes in order to isolate the force only on those joints of the bridge. Students calculated the amount of force acting on each member of the bridge by using the Method of Joints. The Method of Joints is a process of using component vectors and right-angle trigonometry $(\mathrm{G} 1.3 .7)$ to determine the distribution of forces in each member of the bridge. The force acting on their bridges due to gravity was calculated (P3.2C, P3.4C). They identified this force as weight due to gravity (P3.1A).

The High School Content Expectations were assessed using a portfolio assessment. All calculations, rationale for design decisions, etc were included in the portfolio. After each segment of the project, students reflected on the results of their data. They answered such questions as to why the bridge members failed, what errors could have been produced in the experimental data, and how they could use this information to change and improve their bridges (P1.1B, P1.1E). All of the decisions 
made by the team were rationalized in their portfolios (P1.1g). The students' achievement of the HSCEs were supported through applying the mathematic calculations shown in the portfolio as well as the metacognition that supported the achievement of the inquiry HSCEs I (P1.1A, P1.1B, P1.1C, P1.1E).

\section{Research Questions}

1) To what extent will a project-based activity affect the students' attitude toward science and physics?

2) To what degree will students be able to demonstrate their understanding of applied physics concepts using a portfolio assessment?

\section{Variable Definitions}

The dependent variables are:

1) Students' attitude toward learning.

a. Student attitude is defined as their level of agreement with statements from the student survey.

2) Understanding how to build a structurally sound and cost-effective bridge.

a. Understanding is defined as being able to show and explain the application of physics and trigonometric principles to determine how to design and build a cost-efficient bridge.

The independent variables are:

1) Implementing the project-based assignment: building file folder bridges

2) Portfolio assignment: students' project work is collaborated 


\section{Measurement Tools}

Students were given a twenty-question survey pertaining to attitudes toward science and math. Understanding was measured through student portfolios. A rubric was used. Students showed their applied trigonometry skills when determining the member forces. Students were given questions from the member testing activity and bridge building activity. These were answered in the portfolio. The students also made predictions for failure of the bridge and gave a rationale based on their math. After testing the bridges, students evaluated the actual failure point in their bridge and gave rationale as to why the bridges failed there. They also gave suggestions on how to improve their bridges to be more efficient.

\section{Hypothesized results}

It is my belief that students' attitudes towards physics will improve after this project because of the meaning that will be given to the physics concepts that are incorporated into the project. I do not believe there will be a large change in the students preferred learning methods. I believe the students will already prefer learning through projects and hands-on activities. After the implementation of this project, they will still prefer these methods. Additionally, I believe the interest level in engineering as a career choice will also show positive results. In the past, other students that participated in this project showed an increase interest in exploring the field of engineering. As an assessment tool, students complete a portfolio rather than a traditional end of unit test. I believe students will prefer this method of assessment versus a more traditional testing method. 


\section{Data Collection}

Student surveys were conducted to determine students' attitudes towards the class in general, reaction to the unit, reaction toward working cooperatively, and towards engineering in general. This information helped to determine if the application of the project could possibly help students seek science or engineering as a career interest.

A portfolio was used as the final assessment of this project. Such requirements of the portfolio included the calculations needed to determine internal member forces, as well as, a hypothesis of where the bridge failed and the analysis of why the bridge failed.

\section{Possible Effect of Research}

It is my hope that a project-based unit such as this can show positive results in students' attitude towards science. I would like to use these results to explore implementing project-based learning in the district's science curriculum. Also, I would like portfolio assessments to be a viable alternative for measuring student achievement in order to provide variety in assessment tools within the classroom.

\section{Resources Available}

The primary source for the implementation of this project was Stephen J. Ressler's (2002) manual, Designing and Building File-Folder Bridges: A Problem-Based Introduction to Engineering (DBFFB). The West Point Bridge software was used by students to discover how changes in the members of the truss change the distribution of the force along the bridge.

In addition to using Ressler's (2002) manual as a guide to building the bridges, students used the text "Holt Physics" (Serway and Faughn, 2002). Lessons and 
homework examples were pulled from this text as a precursor to the bridge building and member calculations.

The Michigan HSCEs (2006) provided by the Department of Education was used to outline the standards and benchmarks that must be met in Math and Science.

Materials that were necessary for building members and bridges are: file folders, glue, mechanical pencils or ball-point pens, rulers, $36 \times 24$ inch pieces of poster board for posters, wax paper, pins, and a scrap-booking slide cutter. Sand was used when testing the compression and tensile strength of the members and when testing bridges. A tension/compression tester was constructed using wood $(1-1 \times 4,2-1 \times 2)$ five screws, one $1 / 4 \times 2$-inch machine bolt and wingnut, a bucket, and sand.

\section{Timeline}

A general timeline was developed as a guide to pacing myself through the project. Table 2 shows the general timeline for the preparation, implementation, and analysis of the project . 
Table 2. General timeline for project.

\begin{tabular}{cl}
\hline Week & \multicolumn{1}{c}{ Description } \\
\hline 1 & Unit plan development, rubric development, and material preparation \\
2 to 4 & Implementation of plan and instructional time \\
& Student pre-surveys \\
& Lectures and instruction on forces, bridges and components. \\
& Testing of structural members and truss bridges \\
& Development of portfolios \\
& Student post-survey and questionnaires \\
5 to 6 & Evaluation of data \\
\hline
\end{tabular}


(This page deliberately blank) 


\section{Chapter 2-Literature Review}

Many high schools dedicate one day per year to career day during which students are allowed to meet with professionals from the community in order to ask questions about their careers in hopes of getting an idea of what careers they themselves may be interested in. However, these experiences should be presented to students every day in their classrooms. Therefore, if students are to be enticed into a career field like engineering, students must have exposure to what is involved in the engineering process in the classrooms.

Physics is one subject that is a core to engineering. Forces, vectors and Newton's Laws are vital components to consider when determining sound structural design. Through this project-based unit, students blend these physics concepts with fundamental engineering processes.

Students evaluated the forces in a bridge after designing, analyzing, and testing file folder bridges. Students were able to identify the job of structural engineers by roleplaying while implementing their understanding of forces, vectors and Newton's Laws of Motion when designing and building the bridges.

\section{Traditional Approaches to Learning}

Learning is described as building new knowledge using an already established base knowledge, or association of facts and principles (Chinowsky, 2006; Gijselaersz 1996). Learning can be established through many different instructional scenarios. One type of instruction scenario is traditional teaching. Traditional teaching can be equated to a lecture format, during which the lessons are teacher-centered and the extent of students' 
participation is a "three-step system of lecture, reading and homework, and testing" (Chinowsky et al, 2006; Angelides et al, 2000). Learning in a traditional setting, limits the students' knowledge base to what is taught by the instructor or a book; there is little integration of concepts with the real world ideas (Chinowsky, 2006). Contrarily, projectbased learning (PBL) requires students apply the material learned from lecture or textbooks to solve a problem before them (Railsback, 2002). For the purposes of this research, I will concentrate on PBL and traditional scenarios because the preferred teaching style in the science department has been traditional teaching scenarios.

\section{Project-Based Learning}

Quite often, teachers use projects during a unit as an add-on activity to supplement previous lectures (Railsback, 2002). Project-based instruction is not an addon approach to teaching. Instead, it engages students in realistic problems or investigations within the content area (Chinowsky, 2006). Rather than students being in a 'passive state,' students are engaged in applying their knowledge and problem solving skills (Lutz and Schachterle, 1996). Students are introduced to interdisciplinary projects in order to draw out the strengths of each student in the cooperative project. Projectbased instruction does not rely on lecture as the sole method of delivery, rather, it involves students in investigative, inquiry-style learning (Railsback, 2002).

Research on PBL shows mixed results in student achievement in PBL settings versus traditional settings. Beers and Bowden (2005) showed no significant difference in post-test results between traditionally based learners and PBL learners. However, when retested a year later, the long-term the PBL learners scored higher on a content retention 
test than traditional learners (Beers and Bowden, 2005). Using a t-test to compare mean scores, they found $\mathrm{t}=-3.38(\mathrm{df}=44, \mathrm{p}=.002)$. Beers and Bowden $(2005)$ concluded the difference between the scores of the traditionally taught and PBL taught classes was significant. Beers and Bowdens' (2005) research implies that PBL can help students retain the content information for a longer period of time.

The planning and preparation that goes into PBL lessons is extra work on the teachers' part. If this is so and achievement in curricular content is not significantly different, why would teachers want to implement PBL lessons? With PBL, students partake in a different kind of learning (Gallagher, 2000). Traditionally in American science education, learning has been measured by students reciting their memorization of facts underlined in the benchmarks rather than understanding and application of facts (Gallagher, 2000). When PBL opportunities are implemented, not only are benchmarks addressed but students' critical thinking and teamwork skills (Beers and Bowden, 2005) and attitude towards learning improve (Beers and Bowden, 2005; Bechtel, Davidhizar, and Bradshaw, 1999; Willis et al, 2002).

PBL targets higher order thinking skills such as cognitive and metacognitive skills. Metacognition is having awareness for the process of learning (Sigler and TallentRunnels, 2006). Metacognition includes such activities as planning, monitoring, comprehending and evaluating a given task. Cognitive PBL situations include solving problems, manipulating variables, (Chen and McGrath, 2004) and are the basis for what “scientific thinking" is (Helle et al, 2006; Dewey, 1933). Through PBL, students produce problem-solving skills via cognitive and metacognitive skills (Helle et al. 2006; Veenman et al. 2004). 
Although PBL does promote higher order thinking, Chen and McGrath (2004) have found some difficulties in incorporating project-based instruction. Some particular types of difficulties that are addressed in cognitive PBL are conceptual learning, knowledge transfer, and self-regulation (Chen and McGrath, 2004). According to Chen and McGrath (2004), strengthening these sub-categories of cognitive PBL can help learners obtain a "greater understanding and ability to apply that understanding." This is because students must process knowledge content by using "knowledge-transforming not just knowledge-telling skills" during cognitive PBL (Chen and McGrath, 2004).

Lutz and Schachterle (1996) describe PBL as just one form for delivery of information. Traditional instruction is necessary to accomplish certain tasks like establishing a knowledge base on which to reflect (Lutz and Schachterle, 1996). However, neither traditional nor PBL-style instruction should be the only forms of delivery of information (Lutz and Schachterle, 1996). Both methods are necessary to accomplish learning goals that are outlined by an instructor (Lutz and Schachterle, 1996).

\section{Designing and Building File Folder Bridges}

The West Point Bridge Design Contest was created by engineers at West Point Military Academy (Ressler, 2002). The computer program, West Point Bridge Builder@, is the basis for the contest. It was developed for middle and high school students as an introduction to the engineering process in the classroom (Ressler, 2002). During the competition, students use the computer program, West Point Bridge Builder® to build a strong, light-weight, and cost-effective bridge. Teachers are encouraged to use the program as a tool in the classroom even if their students do not participate in the nation- 
wide competition during which students submit their computer-generated designs of bridges (Ressler, 2002).

In addition to the computer software, a PBL activity workbook has been developed. This project-based design was created by Stephen J. Ressler (2002) with the four learning objectives. These objectives are:

- Learn about engineering through a realistic, hands-on, problem solving experience.

- Learn about the engineering design process - the application of math, science, and technology to create devices and systems that meet human needs.

- Learn about truss bridges and how they work.

- Learn how engineers use the computer as a problem-solving tool.

--West Point Bridge Design Contest Purpose and Goals, 2006. The manual, Designing and Building File-Folder Bridges, has five activities that lead students to a problem-based situation in which a township is accepting bids from area contractors to replace a damaged truss bridge. Students will use Ressler's (2002) manual as a guide to the final bridge construction.

Projects that include the application of knowledge by building scale models or computer models are important to implementing an engineering curriculum (Chinowsky et al, 2006). In a traditional setting, students are not integrating concepts from lecture with real world applications. This leads to a limited understanding of the concepts that are being taught in a curriculum (Chinowsky et al, 2006). By assimilating traditional and 
model building of bridges, students claimed in a student survey they had a deeper understanding of the content within a specific curriculum (Chinowsky et al., 2006).

Research indicates students' confidence and commitment to engineering will improve using the West Point Bridge Program. Ellis, Scordilis and Cooke (2003) research shows 96 percent of the students surveyed agreed or strongly agreed that they had a better understanding of the fundamental principles in calculating the forces in the bridge while using the West Point Bridge Program. Students were surveyed and Ellis, Scordilis and Cooke (2003) before and after using the West Point Bridge Program. They grouped the agreed and strongly agreed responses together and found students' agreement with the statement concerning confidence in their understanding of engineering increased by $70 \%$, while their agreement with the statement concerning commitment to engineering increased from $56 \%$ to $69 \%$ (Ellis, Scordilis, and Cook, 2003).

In addition to a deeper understanding of math and science, Symans (2000) claims projects like bridge building help cultivate students' understanding and interest in science and math-related careers like engineering. It is imperative for educators to implement engineering applications in the curriculum in order for students to consider engineering as a career option (Symans, 2000).

Through PBL, the learning can become more relevant because of the connection to learning knowledge in the context it will be used in (Shanley, 1999). Chinowsky et al (2006) explain that "engineering is a knowledge transformation process" and as a result, engineering implements PBL opportunities for students. Yildirim (2004) feels when 
knowledge becomes relevant to solving a problem, student attitudes should improve because students develop an "ownership of knowledge".

\section{Project-Based Learning and Attitude}

A positive correlation has been found between self-efficacy, attitude and achievement (Lui et al, 2006). Having a better understanding could result in higher selfefficacy, the belief that one can successfully complete a task (Lui et al, 2006, Bandura, 1986). Self-efficacy as been shown to improve attitude; as a result achievement improves (Lui et al, 2006). Therefore, through cognitive PBL, the potential for deeper understanding of physics could result in a better attitude towards subject matter (Lui et al, 2006). In a vicious cycle, the project will promote deeper understanding by using metacognitive and cognitive skills, this will harvest a greater self-efficacy, and therefore improve learning. This belief that one can do it, would keep students' attitude high and therefore more achievement through understanding will occur (Lui et al, 2006).

Yildirim (2004) focused on student attitude towards grades and group work. Students worked with others that they did not necessarily have prior experience working with (Yildirim, 2004). He found a positive correlation between achievement and group work. This is credited to the students' final year of high school and the anticipation of entering the workforce with strangers they are not accustomed to. Also, he gave big kudos to the students' previous experiences with group work and PBL. Yildirim's study also found that there was a negative correlation between work avoidance and GPA. The findings between work avoidance and GPA point out important factors to consider when teaching honors students using PBL. 
There may not be a significant improvement in attitude towards physics simply because PBL is implemented. It has been found that students who are motivated by GPA find this type of "extra work" to be contradictory to a positive learning environment. This type of mindset may contradict what PBL researchers say about improved attitude towards subject matter during PBL activities because the subjects in this experiment have not been exposed to PBL throughout their career.

\section{Portfolio Assessment and Project-Based Learning}

The goals of creating a deeper cognitive understanding through project-based learning do not allow solely for traditional assessment strategies (Frank and Barzilai, 2004). Traditional assessments often include the recall of facts (Tigelaar, et al., 2005; Dochy, et al., 1999) rather than an opportunity for students to exhibit their development of learning through a collection of work and reflections like a portfolio provides (Gulbahar and Tinmaz, 2006; Barret 2001). Through portfolio or journal-style assessments, students are able to show their understanding through reflections of their work, progress and goals (Gülbahar and Tinmaz, 2006). Portfolios include expression and justification of the subjects' thinking (Kubler-LaBoskey, 2000).

Students demonstrate justification and critical thinking through reflective writing in portfolio assessments during PBL (Lynch and Purnawarman, 2004). For example, in Nickelson's (2004) development of portfolios in Physics, he has students interpret information from graphs, explain the relationship of physics to real-world examples, and solve mathematical physics problems by combining the math with the application of it. These are all higher order thinking skills (Lynch and Purnawarman, 2004). Nickelson 
(2004) believes portfolios show a more accurate picture and a student's deeper understanding of what is actually known. This is because students show their understanding of the material by explaining how their work in the portfolio meets the learning standards (Nickelson, 2004). Rather than have students do this, my students completed the requirements in the portfolio. These requirements were based on the state standards.

Through PBL and portfolio assessment in engineering, researchers feel students gain experience in "written communications, budgeting, project scheduling and management, team dynamics and conflict resolution (Lutz and Schachterle, 1996).” In order to build these skills appropriately, students must have reliable support by the teacher. Lutz and Schachterle (1996) provide a list of support they feel is needed for successful PBL practices in engineering. Such criteria include report preparation assistance, laboratory operations, and material supplementation.

\section{Reliability and Validity of Portfolio Assessment}

The validity of the assessment is determined by the fact that the assessment tool must measure what it was designed to measure (Tigelaar, et al, 2005). In this case, the portfolio was designed to measure if students met the HSCE's outlined in Table 1. The validity of this portfolio may need more attention because it is based on the lessons and assignments from the manual.

Wolf (1998) claims that reliability is difficult to establish in portfolio assessments. This is because it is "impossible to develop written descriptors so tight that they can be applied reliably by multiple assessors." The key to developing the most reliable 
assessment tool is to develop the portfolio requirements so that they meet specific standards (Wolf, 1998). In this case, the portfolio was developed to meet the HSCE's outlined in Table 1. Table 12 shows where each of the HSCE's are measured in the portfolio.

While portfolios offer a teacher an insight to the students' level of understanding, there must be some drawbacks to portfolio assessment verses traditional testing. The greatest detriment found through Gülbahar's and Tinmaz's (2006) analysis of portfolio assessment was that students had difficulties maintaining deadlines and being selfmotivated. As a result, students felt they had to put forth more effort than in traditional testing assessments and felt overloaded with work (Gülbahar and Tinmaz, 2006).

Learners found documentation of learning activities tedious. In addition Gülbahar and Tinmaz (2004) speculate that these variables can inhibit the learning objectives of the project.

Other drawbacks to PBL and portfolio assessment are students' familiarity with the teaching and assessment style (Hays, 2004). Hays (2004) reports that many students have little experience in self-directed learning, which is essential in PBL and portfolio assessments. Additionally students become accustomed to traditional-style teaching and testing (Hays, 2004).

In portfolio assessments, students must keep records to track their project's progression. Many learners find this to be tedious and would rather focus on curriculum (Hays, 2004). To overcome the shortfalls of portfolio assessment, teachers must provide students with a clear and concise set of guidelines for the portfolio. 


\section{Chapter 3-Procedures}

The focus of this research was to determine if students' attitudes towards physics, related careers, and learning preferences would change after implementation of projectbased learning practices. A twenty statement, multiple-choice survey completed by the students was also used to determine if there was a preference towards portfolio assessments over traditional assessments. Additionally, students' were assessed using portfolios rather than a traditional end of unit test.

Two research questions were addressed:

1) In what way would a project-based activity affect the students' attitude toward science and physics?

2) Will students be able to demonstrate their understanding of applied physics concepts using a portfolio assessment?

In addition, three sub-questions were asked:

1) To what extent did the project-based assignment change the learning preference of the students?

2) Will students' interest in science related careers like engineering change?

3) Do students prefer portfolio assessments rather than traditional assessments?

\section{Subjects}

Elk Rapids High School is a rural town 18 miles north of Traverse City, Michigan. Approximately 8000 people live in the town and surrounding community. The district superintendent has made many efforts to make the school system the heart of this small community. Some school-centered events are the community business expo 
hosted at the high school, community tailgating plaza for pre-game football festivities, and the only auditorium in the community to host guest speakers, plays and musicals.

The school board makes sure the community, and therefore students, have some of the best facilities available for use. High standards by the community, board of education, and staff of Elk Rapids Schools bring many school-of-choice students to our district. In the high school alone, approximately 15 percent of our student body is composed of school-of-choice students.

Besides the small school atmosphere Elk Rapids provides, one other attractant for school of choice students is the academic reputation of the students. Prior to state mandated ACT participation, approximately 60.2 percent of the Elk Rapids student body participates in ACT testing and scored an average composite score of 20.9, just below the state average of 21.4 with 56.3 percent tested (Standard and Poors, 2007). Elk Rapids falls between neighboring schools like Traverse City Central (23.0) and Kalkaska (20.4) who test only 51.8 percent and 44.6 percent respectfully (Standard and Poors, 2007).

The student body of Elk Rapids High School has approximately 520 freshman, sophomore, junior and senior students. For a small school, there is a large selection of courses that a student can choose from. This includes honors courses such as Advanced Placement Chemistry, Advanced Placement Biology, and Honors Physics.

The subjects for this study were eighteen junior and five senior students who attend Elk Rapids High School in Elk Rapids, Michigan. Due to the level of algebra and trigonometry involved, physics is offered as an honors course every other year to juniors and seniors who have completed or are in the process of completing algebra III. All physics students have also taken pre-physics. Pre-physics is a conceptual physics course 
offered to freshmen. It does not incorporate math with the conceptual lessons and is taught using non-PBL teaching methods.

There is only one section of physics offered to students at Elk Rapids High School. Therefore there is no control group with which to compare the results of this action research.

\section{The Teacher}

This was my fifth year teaching and second year teaching physics. My background is in Biological Sciences with a Bachelor of Science from Michigan Technological University. I have a minor in General Sciences and Mathematics from Saginaw Valley State University. As a full-time teacher, my class load includes biology, advanced placement biology, human physiology, botany, and environmental science.

There was a ten-year absence of honors physics from ERHS. Because of the absence of honors physics taught in the school, there were no lesson plans developed. I began teaching this subject with no previous lesson plans to draw from. My intention for choosing this masters program and this project in particular was to improve my skills and knowledge in physics.

One physics course was taught during a 55-minute period each day. The course was taught with a mix of inquiry-based instruction and traditional instruction throughout the year. This unit was implemented in the winter of 2006. The text, "Holt Physics" (2002), was used as a guide to the mathematical applications of physics in a traditional style of teaching. In addition to traditional teaching methods, PBL activities were used to solidify conceptual principles of physics. 


\section{Instructional Unit}

An example of one inquiry activity that was applied in earlier lessons was mapping and adding vectors. Students were given a stack of ten cards with a distance and a direction written on them. The students measured out the distance in the direction given on the card. After working through all ten cards, the students should have ended up at a numbered flag. The students then mapped out their path taken using graphing paper and vector diagrams to show the resultant of all of the ten measurements. The students repeated the lab after shuffling the cards. Through this inquiry activity, students learned no matter what order you add the components; the resulting vector would be the same. Students then followed up this activity with some traditional sample homework problems provided in the text.

The goal of this instructional unit was to teach students about applied forces using a project-based curriculum. The Forces and Motion HSCEs (Michigan High School Content Expectations, 2006) were addressed after students were presented with a need statement from a fictional customer. It was necessary for students to be presented with a proposal or need statement to identify the content they would need to know for the project (Lutz and Schachterle, 1996). This unit combined traditional lecture with an inquiry activity in order to foster the students understanding of the content. Students worked in groups of three and one group of two. Lutz and Schachterle (1996) suggest that groups no larger than 3 or 4 students are necessary to keep learners actively engaged. A sequence and timeline for the unit is presented in Table 3. 
Table 3. Lesson Sequence and Objectives

\begin{tabular}{|c|c|c|}
\hline Day & Activity & Procedure \\
\hline \multirow[t]{18}{*}{1,2} & Present Need & Students were given the pre-survey to complete \\
\hline & Statement and & in class. \\
\hline & Introduce Structures & Students were presented with the goal of the \\
\hline & of a Truss Bridge & project, and have an outline of the rubric for \\
\hline & & their portfolios. Students were reminded of the \\
\hline & & engineering process presented in a previous unit \\
\hline & & (Appendix D). \\
\hline & & Lesson 1: Students were introduced to contact \\
\hline & & and field forces. Students calculate magnitude \\
\hline & & of forces (Serway and Faughn, 2002, p 124- \\
\hline & & 128). Students were introduced to Newton's \\
\hline & & First and Second Laws (Serway and Faughn, \\
\hline & & 2002, p 130-140) (See outline for lesson in \\
\hline & & Appendix D) \\
\hline & & Lesson 2: Components of a truss bridge. Follow- \\
\hline & & up with class discussion of the forces applied to \\
\hline & & a bridge. (Appendix $\quad \mathrm{D}$ PowerPoint ${ }^{\circledR}$ \\
\hline & & presentation) \\
\hline \multirow[t]{3}{*}{3} & Compression and & Through observation of demonstrations, students \\
\hline & Tension Members In & used appropriate terminology to explain factors \\
\hline & a Bridge & of a member that affect tensile \\
\hline
\end{tabular}

table continued 
Table 3 (continued).

and compressive strength of the structural member (Ressler, 2002, p 2-1 - 2-28).

4,5 Build and Test

Structural Members

in a bridge

6,7 Collaborate

Experimental Data

8,9 Bridge Design

10, 11 Calculating Forces

In a Truss

12 Apply for Permits
Students determined tensile and compressive strength of structural members through experimentation.

Students used a computer spreadsheet to graph and analyze experimental data.

Students worked with West Point Bridge(C)

software to design a "cost-effective" bridge.

Students use data from days six and seven to determine the size of the bridge components.

Students use trigonometry and the method of joints to determine how the forces will be distributed through their truss bridge on the day of testing.

Students will propose bridge design to the county to apply for permits (get an approval to proceed with bridge design). At this point, students started building their bridges or redesigning bridges. 
Table 3 (continued).

13, 14 Bridge Building

Students had an additional day to work on building their bridges. Students must finish building bridges on their own. They were given 5 days to build ( 3 school days, two weekend days).

15 Bridge Testing Day

Students tested to see how well the bridges hold up under $59 \mathrm{~N}$ of force.

16 Portfolio

Students have an opportunity to ask questions to Assessment clarify the requirements for the portfolio. Students work to complete the analysis of their bridges for their portfolios.

$17-20$ Students have time to work on portfolios out of class

$21 \quad$ Portfolio Students turn in portfolios and complete postAssessment Due survey and student questionnaire. 


\section{Need Statement Overview}

The Designing and Building File-Folder Bridges manual explains the need statement as the following:

The Need: Recently a tractor-trailer truck lost its breaks while driving on Grant Road. The driver lost control of the vehicle, and it collided with one of the end posts on the west end of the Grant Road Bridge. Fortunately, no one was hurt, but the bridge was damaged beyond repair. Grand Road is now closed, and the Town of Hauptville has initiated a project to replace the structure as quickly as possible.

(Ressler, 2002, p 5-5)

With the need statement in mind, students were introduced to the concept of forces and Newton's first and second laws of motion. The students were also introduced to the the parts of a truss bridge and how those parts aid in the distribution of forces throughout the bridge. Students had been introduced to the engineering process as presented by Knight, et. al. (2006) in previous lessons (Appendix D). The engineering process was reviewed by the class.

After presenting the need statement, two traditionally-styled lessons were implemented to give them the background information about forces and bridges (Appendix D). On day 3, students began constructing tension and compression members to test the strength of them. Students continued testing and analyzing data until day 7. Using the data, students designed a computer simulated bridge using West Point Bridge 
Builder(C. The students were able use the computer software to test multiple variables when determining the structure of the bridge members. Some of these variables were the effects width, length, hollow, and solid members. Students calculated the determinacy of their bridges to decide if they could use the method of joints to calculate the forces in each member of the bridge (Appendix D). If the students could use method of joints, they had to then apply for permits (get it approved by the instructor). Upon approval, students were given until day 14 to redesign or start constructing their bridge in class. On day 15 , students tested their bridges. Day 16 was spent clarifying requirements for the portfolio and students were able to collaborate information for the portfolio. On day 21, the portfolios were collected and the students were given the post-survey.

\section{Overview of Unit Objectives}

Student lessons were focused around building a file-folder bridge using guidance from the manual, Designing and Building File Folder Bridges (Ressler, 2002). The unit was launched by presenting the need statement for the bridge that the students would need to design and build (Appendix D). Concepts of physics were incorporated through some lectures and three central learning activities.

The students' first task was to conduct experiments to test the individual member strength, or the amount of force one member can take before it fails. The force applied to a truss bridge is distributed throughout the truss so that each support member within the truss carries some of the total force. Some of these members will be in tension, or stretched, when force is applied to the bridge. Contrarily, some of the members of the bridge will be in compression, or squished, when the force is applied to the bridge. Students made compression members of different lengths and widths from file folders. 
Students also made tension members of different lengths and widths from the same material. Using a compression and tension testing apparatus built from the instructions found in Ressler's manual (2002), students determined how much force compression and tension members of different dimensions could hold before it would fail (Appendix D). Students plotted and analyzed their data using Microsoft Excel ${ }^{\circledR}$. The students plotted the length of the member versus total force held before failure for the tension and compression members. Additionally, the width of the member versus the mass held before failure was also plotted. Using this data, students determined which size members would work best in their bridges to reduce the overall mass of the bridge.

Since this was a high school level course, the students were limited in the type of truss bridges they were able to analyze. The students used trigonometry principles in the Method of Joints analysis. The Method of Joints uses an equation of equilibrium in which the sum of the forces will equal zero.

In the second activity, students used the computer software West Point Bridge Builder@ (Ressler, 2002) to develop a structural design for their bridge. After fabricating a determinant bridge, one that can be analyzed using the equation of equilibrium, the students evaluated the applied forces in each member of the truss using trigonometry from HSCE G1.3.1 and the Method of Joints analysis.

Following the students' calculations of forces within each member of the truss bridge, they were able to start the third activity. During this activity, students constructed a file-folder bridge and tested their model bridge under approximately $59 \mathrm{~N}$ of force. The weight of $59 \mathrm{~N}$ was used in the manual as a requirement for how much the bridge should hold. 
In the course of the bridge design PBL unit, each student group created a company name that they would go by when trying to sell their bridge design to the township. The students' goal was to make the most efficient bridge of all the "companies" in the class. The most efficient bridge was determined by the lightest and most cost-effective bridge that met the requirements set forth by the township.

A formula that included the "cost" of the members of the bridge, as well as the mass, was used to determine the winning bid from one of the student companies. The number of members of the truss, the number of joints and the mass of the bridge itself were components to determining the cost of the bridge. The formula used is listed below.

Bridge Score $=\operatorname{mass}[3(\#$ joints $)+2(\#$ compression members $)+1(\#$ tension members $)]$

After the bridge score was determined, the bridges were tested to see if they would hold the $59 \mathrm{~N}$. If the bridge did hold under the load, the bridge score was multiplied by 1 . If the bridge did not hold the load, the bridge score was multiplied by 0 . This final score was used to determine which team's bridge would be accepted by the city council.

\section{Michigan High School Content Expectations (HSCEs)}

The Michigan High School Content Expectations have been built around inquiry and student-centered education in the classroom. Project-based learning is one form of 
inquiry, student-centered education (Railsback, 2002). Within this unit, students were presented with a need statement by a fictional customer and parameters within which to build the bridge. The customer requested a traditional truss bridge design to replace the old one that had been damaged. However, the bridge also needed to be lightweight and cost effective. With this in mind, students explored different ways to limit the weight by manipulating different variables such as the length and width of the members of the truss, as well as, the number of members in the bridge when they chose a design. Through these inquiry-based exercises, students are exposed to Standard P3 (Forces and Motion) of Michigan Essential and Core Physics expectations. Table 4 shows the HSCEs that were addressed in the lessons of this unit. 


\section{Table 4. Michigan High School Content Expectations (HSCE) Addressed in File-Folder Bridge Lessons}

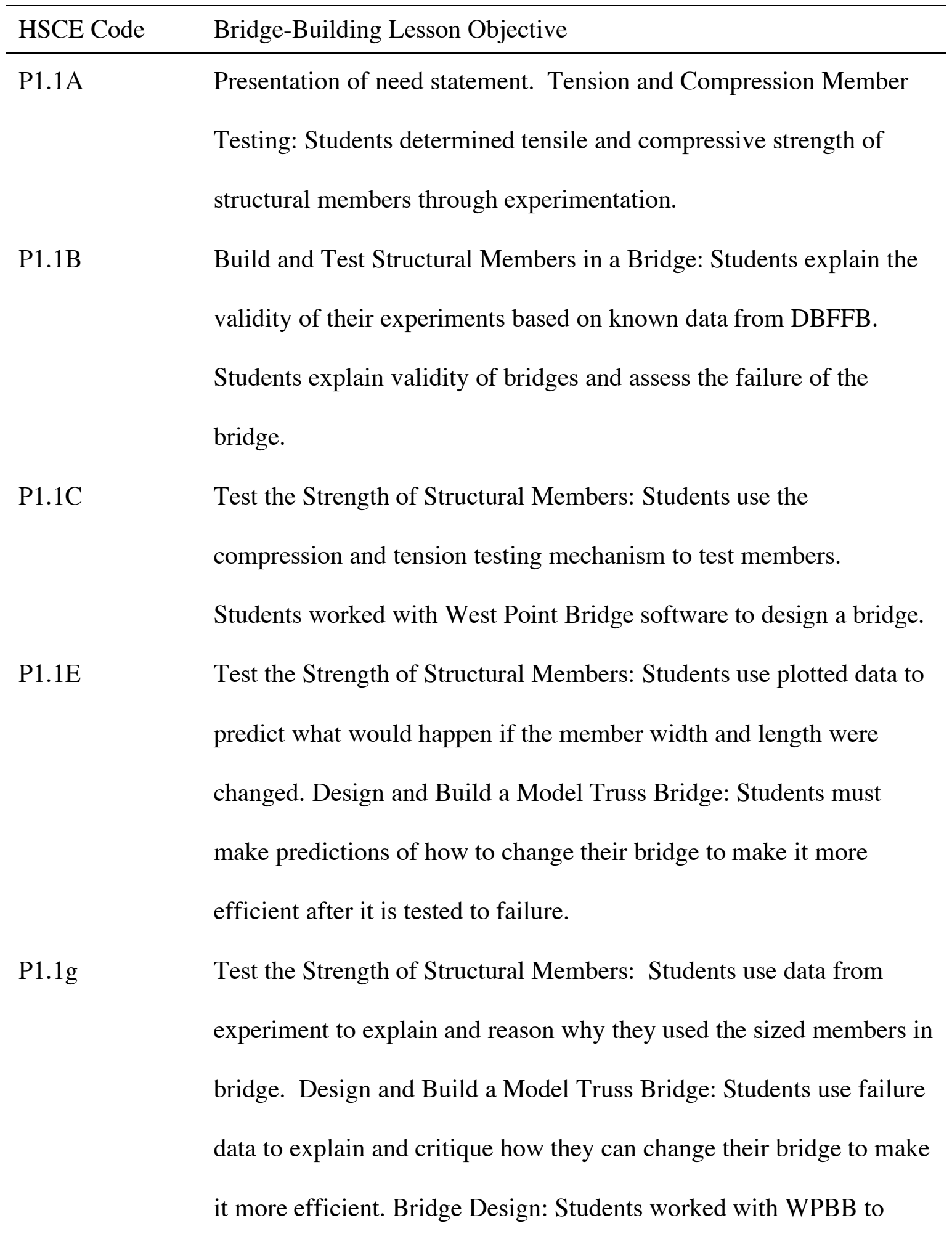

table continued 
design a structurally sound, cost-effective bridge. Students use data from structural member tests to determine the size of bridge components.

P1.1h Compression Member Testing: Students use a computer spreadsheet to graph and analyze experimental data from testing.

P3.1A Lesson 1: Students were introduced to contact and field forces. Lesson 2: Components of a truss bridge were presented to class. Class discussed the forces applied to a bridge.

P3.2A Lesson 1: Students calculate magnitude of forces. Lesson 2: Class discussion of forces applied to a bridge.

P3.2C Lesson 1: Students calculate magnitude of forces. Calculating Forces in a Truss: Students use trigonometry and the method of joints to determine how the forces will be distributed through their truss bridge on the day of testing.

P3.4C Lesson 1: Students calculate magnitude of forces. Calculating Forces in a Truss: Students use trigonometry and the method of joints to determine how the forces will be distributed through their truss bridge on the day of testing.

G1.3.1 Lesson 1: Students calculate magnitude of forces.

Calculating Forces in a Truss: Students use trigonometry and the method of joints to determine how the forces will be distributed through their truss bridge on the day of testing. 


\section{Portfolio Design and Development}

The second and fifth questions addressed portfolio assessments. The subjects used portfolio assessments to demonstrate their understanding of physics. In the portfolio, the students presented the problem, predictions, experimental results, rationale and metacognition in relation to the design and building of their bridge. Student attitude toward portfolio assessments was determined through the student survey. Students ranked their preference for teachers' use of portfolio assessments on a scale from strongly disagree to strongly agree.

The portfolio rubric (Appendix A) requires student metacognition, their explanation of what they chose to do and why they chose to do it. Additionally, the portfolio requirements included some traditional assessments through solving for the forces in individual members of a sample bridge. This was done to ensure that students could transfer the knowledge from their bridge-building situation to another situation.

In order to obtain student work that shows understanding on their part, there must be a concise rubric or set of expectations laid out for students (Railsback, 2002). Therefore, a detailed grading rubric was supplied so that students knew exactly what to put in the portfolio. The grading rubric for the portfolios was created using the guidance of Nickelson's article. The bulk of a portfolio was to make connections between the physics concepts and student's learning, knowledge and skills (Nickelson, 2004). For example, students needed to calculate the forces within each bridge member and decipher if the member is in compression or tension. They would then apply this information to construct the correct type of member in the bridge. 
The content of the portfolio was specifically designed to cover the benchmark addressed in the HSCEs. For example, P1.1g deals with using empirical evidence to rationalize decisions made in science. Students had to use the data from the tension and compression member tests to determine how large to make the members in the bridge.

\section{Survey Development}

The data from the pre- and post-surveys addressed the first research question about students' attitude toward science and physics. The survey (Appendix B) also addressed sub-questions three and four pertaining to learning preferences of the students and science careers respectively. The focus of the learning preferences was self-teaching, hands-on experiences, group work, and lecture-style format.

A two-page survey was prepared to assess the students' preferred method of learning and their attitude towards science (Appendix B). The goal of the survey was to determine if students liked science, how they preferred to learn and if they preferred being assessed using a portfolio versus a traditional test. Additionally, statements were presented to establish if students found their education to be relevant in their lives. These included statements about if students watched programs, participated in after school activities, and were interested in careers related to science.

The first twelve statements dealt with the interest level of students in science, related careers, and attitude towards science. These statements were based on research by Jarvis and Pell (2002) and employed by Teubert (2006). The survey statements were developed to determine the students' enthusiasm in science in more aspects than the 
classroom setting alone (Teubert, 2006; Jarvis and Pell, 2002). This is because students' science education is intended to be applicable outside of school.

There was no reliability test done with this survey. Alpha reliability is way to measure the internal consistency of the mean of the items in a survey (Gable and Wolf, 1993). Jarvis and Pell (2002) developed a survey which had an alpha reliability of .65< $\alpha<$.78. An acceptable alpha reliability level is .70 or higher (Teubert, 2006, Jarvis and Pell, 2002). Reliability was assumed because my survey was developed based on Jarvis and Pell's (2002) survey.

Survey statements 13 through 20 pertained to students preferred methods of learning. There was no reliability done for this section of the survey. This portion of the survey was designed by the researcher in order to determine if students had a change in their preferred method of learning. In addition, the survey also addressed portfolio assessments versus traditional test assessments. The intent of this statement was to determine if students preferred traditional or portfolio assessments before and after the activities were implemented.

The survey was administered using a five-point scale in which the subjects were able to strongly agree, agree, neither agree nor disagree, disagree, strongly disagree. When the data was analyzed, each of these responses was given a numerical value: strongly disagree (1), disagree (2), neither agree nor disagree (3), agree (4), and strongly agree (5). Table 5 shows the twenty statements from the survey pertaining to students' attitude toward sciences. The results from these survey statements were used to assess research questions one, three, four and five. 
Table 5 shows the twenty survey questions that were used in the pre- and postsurvey during this project. 


\section{Table 5. Attitude and Learning Preferences Student Survey}

\begin{tabular}{|c|c|c|}
\hline Part & No. & Statement \\
\hline \multirow[t]{10}{*}{ Science } & 1 & I like science. \\
\hline & 2 & Science is fun. \\
\hline & 3 & I am good at science. \\
\hline & 4 & Science is boring. \\
\hline & 5 & Learning about science is important. \\
\hline & 6 & I like learning physics. \\
\hline & 7 & I take part in science-related activities outside of school. (like \\
\hline & & clubs, science kits, etc) \\
\hline & 8 & I like to watch science programs like the ones on Discovery \\
\hline & & Channel. \\
\hline \multirow[t]{5}{*}{ Careers } & 9 & Science is applicable outside of school \\
\hline & 10 & I will use the information I learn in my science classes in the real \\
\hline & & world. \\
\hline & 11 & I would like a career that involves knowing a lot of science. \\
\hline & 12 & I would like a career as an engineer. \\
\hline \multirow[t]{5}{*}{ Preferences } & 13 & I would prefer my teachers assess my achievement through \\
\hline & & portfolios rather than end of the unit or chapter tests. \\
\hline & 14 & I learn best when I find information on my own. \\
\hline & 15 & $\begin{array}{l}\text { I learn best when information is presented to me in a lecture- } \\
\text { style format. }\end{array}$ \\
\hline & 16 & I learn best through hands-on activities. \\
\hline
\end{tabular}


Table 5. (continued)

17 I prefer learning by doing projects.

18 I prefer learning by doing group work.

19 I prefer learning by doing book work.

20 I prefer learning through lab experiences.

\section{Student Questionnaire}

The questionnaire posed specific questions found in Table 6. The questionnaire was designed by the researcher in order to collect detailed comments from the students about this specific project. 


\section{Table 6. Bridge Project Questionnaire for Detailed Student Feedback.}

\section{Question}

Overall, how would you rate this project?

12

Terrible

Great

Please describe what you liked most about the project and give specific details.

Please describe what you liked least about the project and give specific details.

Do you prefer a final test assessment like a chapter test or a final portfolio assessment? Please explain.

During the project, your team worked as an engineering firm that was bidding on a job. Do you feel you have a better understanding of what an engineer does after doing this project? Please comment on what you believe an engineer does as an occupation. 


\section{Procedures}

Railsback (2002) suggests one of the most important things to do in PBL is to be highly organized. Therefore, one week of preparation prior to implementation of the lessons was necessary to create rubrics (Appendix A), surveys (Appendix B), and student questionnaire (Appendix C), as well as, collect supplies and make copies for the students. Table 7 shows the timeline for the research project. 


\section{Table 7. General Timeline for Research Procedures}

\begin{tabular}{ll}
\hline Week & Activity \\
\hline 1 to 7 & Preparation: Development of Rubrics, surveys and \\
& student questionnaires \\
8 to 14 & Administer Pre-surveys, Introduction to Truss Bridges, \\
& Forces and Vectors, and Compression/Tension Forces; \\
& Present Need Statement \\
& Analyze Parts of a Bridge: Build and Test Compression \\
& and Tension Members, \\
& Compile class results from compression/tension tests. \\
& Work with West Point BridgeC, Propose Bridge \\
& Dortfolios \\
& Collect portfolios; Complete Post-survey and Student \\
& \\
&
\end{tabular}




\section{Bridge Testing}

The bridges were tested using a load of $59 \mathrm{~N}$ of force as determined by Ressler (2002) from the combined weight of a sturdy clipboard and a bucket of sand. This load was distributed on 4 points of the bridge. Students determined which 4 points of the bridge they would set the load on. Pennies were placed on the joints that would carry the load in order to assure that the load was set on the joint only not across the members. The clipboard was set on tip of the pennies and the bucket of sand was carefully centered on the clipboard.

After the bridge was loaded, it had to hold the load for 30 seconds. After the 30 seconds, a second bucket was placed on top of the first bucket. Additional sand was slowly placed inside this bucket. The bridge was loaded with additional sand until the bridge failed. The additional sand and bucket were then weighed out to see how much additional mass the bridge held until failure.

The bridge was examined by the students to determine if it had failed where they predicted it would. If it didn't, the students needed to explain why it failed in a different place.

\section{Data Collection Method}

The pre-survey was administered at the beginning of the unit prior to any lessons being presented. The post-survey was administered the day the portfolios were due. Portfolio assessments were collected and graded by me. All students participating in the lessons were present each time the surveys were administered. 
The post-survey was specifically given before the portfolios were graded and returned to students. This is because I wanted to determine if the students' change in attitude was based upon the implementation of a project-based curriculum and the portfolio assessment, not based on an earned grade. Students were also asked to complete a student questionnaire. A copy of the student questionnaire can be found in Appendix C.

\section{Data Analysis}

After the surveys were collected, the responses were given a point value of 1 (strongly disagree) to 5 (strongly agree). Descriptive statistics were used to determine the mean and standard deviation of the items of the pre- and post-survey, as well as the first question of the questionnaire. The effect size was then calculated from the pre- and postsurvey means and standard deviation. The effect size shows the difference in the survey results after the implementation of PBL.

These statistics were used to determine if a change in attitude towards science, physics, and learning preferences occurred and if the changes were of importance. The questionnaires were reviewed to determine specific areas of this project that need improvement. It was also used to determine if students had a basic understanding of what an engineer does. 
(This page deliberately blank) 


\section{Chapter 4-Data Analysis}

The data analyzed for the purpose of this study are from portfolio assessments and pre- and post-surveys containing statements that were administered to 18 junior and 5 senior students. The survey statements pertained to attitudes towards science and preferences in learning styles.

The purpose of the pre- and post-survey results was to show any changes in the attitudes toward science, science related careers, and/or learning preferences. The survey results were also used to determine if students had a change in opinion on portfolio assessments rather than traditional testing.

The purpose of the portfolio assessments was to determine if students could meet the HSCEs benchmarks by rationalizing the steps they took when determining the type of bridge they built based on the distribution of the forces through the bridge.

\section{Pre-survey Data for Assessing Attitude Towards Science and Related Careers.}

A two-page survey was administered to the students prior to starting the unit. The results of the survey were broken into two sets of data: the attitudes toward science and related careers and the attitudes towards learning and assessment preferences. The first set of data analyzed was the pre-survey attitudes toward science and related careers. Table 8 shows the results of the pre-survey data related to student attitude towards science. Raw data was used to determine mean and standard deviation can be found in Appendix E. 


\section{Pre-survey Data for Learning and Assessment Preferences}

The second part of the survey administered prior to beginning the unit, assessed learning preferences of students. The subjects recorded their level of agreement on a 5 point scale from strongly agree to strongly disagree. Students also measured their level of agreement of having their work assessed through a portfolio versus a traditional test. The mean and standard deviation for learning and assessment preferences can be found in Table 9. Raw data used to calculate these results can be found in Appendix E.

\section{Pre- and Post-survey Comparison of Data for Attitude Toward Science and Related Careers.}

Data was collected in a survey in order to determine if there was a change in attitude towards science and related careers after implementing a project-based learning program.

Effect Size. The effect size is the difference between two means divided by the standard deviation from one of the groups within the experiment. The purpose of finding the effect size is to compare the differences between two groups' mean scores from related groups (Bracey, 2000, Shaver, 1985). Bracey (2000) discusses researchers findings of an effect size of +.20 to +.30 to be of importance.

Normally, effect size would use the experimental group minus the control group in the calculation. However, since there was no control group with which to compare these results to, I used the pre-survey means instead of the control group and the postsurvey means instead of the experimental group. The standard deviation from the pre- 
surveys was used to divide the difference between the post-survey data minus the presurvey data. The equation for effect size used in this research can be found below.

$$
\text { Effect size }=\frac{\text { post mean }- \text { pre mean }}{\mathrm{sd}_{\text {pre }}}
$$

For my research, the effect size of +.20 to +.30 would be of importance, +.10 to +.20 would be of small importance, and anything smaller than +.10 would be of little importance.

The effect size for attitudes towards science and science-related careers is shown in Table 8. 
Table 8. Pre- and post-survey change in the attitude of students.

\begin{tabular}{|c|c|c|c|c|c|c|c|c|c|}
\hline \multirow[b]{2}{*}{ Part } & \multirow[b]{2}{*}{ No. } & \multirow[b]{2}{*}{ Statement } & \multirow[b]{2}{*}{$\mathbf{N}$} & \multicolumn{2}{|c|}{ Presurvey } & \multicolumn{2}{|c|}{ Postsurvey } & \multirow[b]{2}{*}{ Diff. } & \multirow{2}{*}{$\begin{array}{c}\text { Effect } \\
\text { Size }\end{array}$} \\
\hline & & & & Mean & SD & Mean & SD & & \\
\hline \multirow[t]{19}{*}{ Science } & 1 & I like science. & 23 & 3.83 & 0.72 & 3.91 & 0.88 & 0.08 & 0.11 \\
\hline & 2 & Science is fun. & 23 & 3.35 & 0.95 & 3.47 & 0.08 & 0.12 & 0.13 \\
\hline & 3 & I am good at & 23 & 3.91 & 0.65 & 3.83 & 0.78 & -0.08 & -0.12 \\
\hline & & science. & & & & & & & \\
\hline & 4 & Science is boring. & 23 & 3.13 & 0.95 & 2.74 & 1.03 & -0.39 & -0.41 \\
\hline & 5 & Learning about & 23 & 4.09 & 0.58 & 4.13 & 0.53 & 0.04 & 0.07 \\
\hline & & science is & & & & & & & \\
\hline & & important. & & & & & & & \\
\hline & 6 & I like physics. & 23 & 3.13 & 1.08 & 2.83 & 1.31 & -0.30 & -0.28 \\
\hline & 7 & I like taking part in & 23 & 4.04 & 0.99 & 4.04 & 0.91 & 0.00 & 0.00 \\
\hline & & science-related & & & & & & & \\
\hline & & activities outside of & & & & & & & \\
\hline & & school (i.e., clubs, & & & & & & & \\
\hline & & science kits, etc) & & & & & & & \\
\hline & 8 & I like to watch & 23 & 4.52 & 0.71 & 4.57 & 0.64 & 0.05 & 0.07 \\
\hline & & science programs & & & & & & & \\
\hline & & like the ones on & & & & & & & \\
\hline & & Discovery Channel. & & & & & & & \\
\hline & & Average & & 3.75 & 0.84 & 3.69 & 0.84 & -0.06 & -0.07 \\
\hline
\end{tabular}


Table 8 (continued).

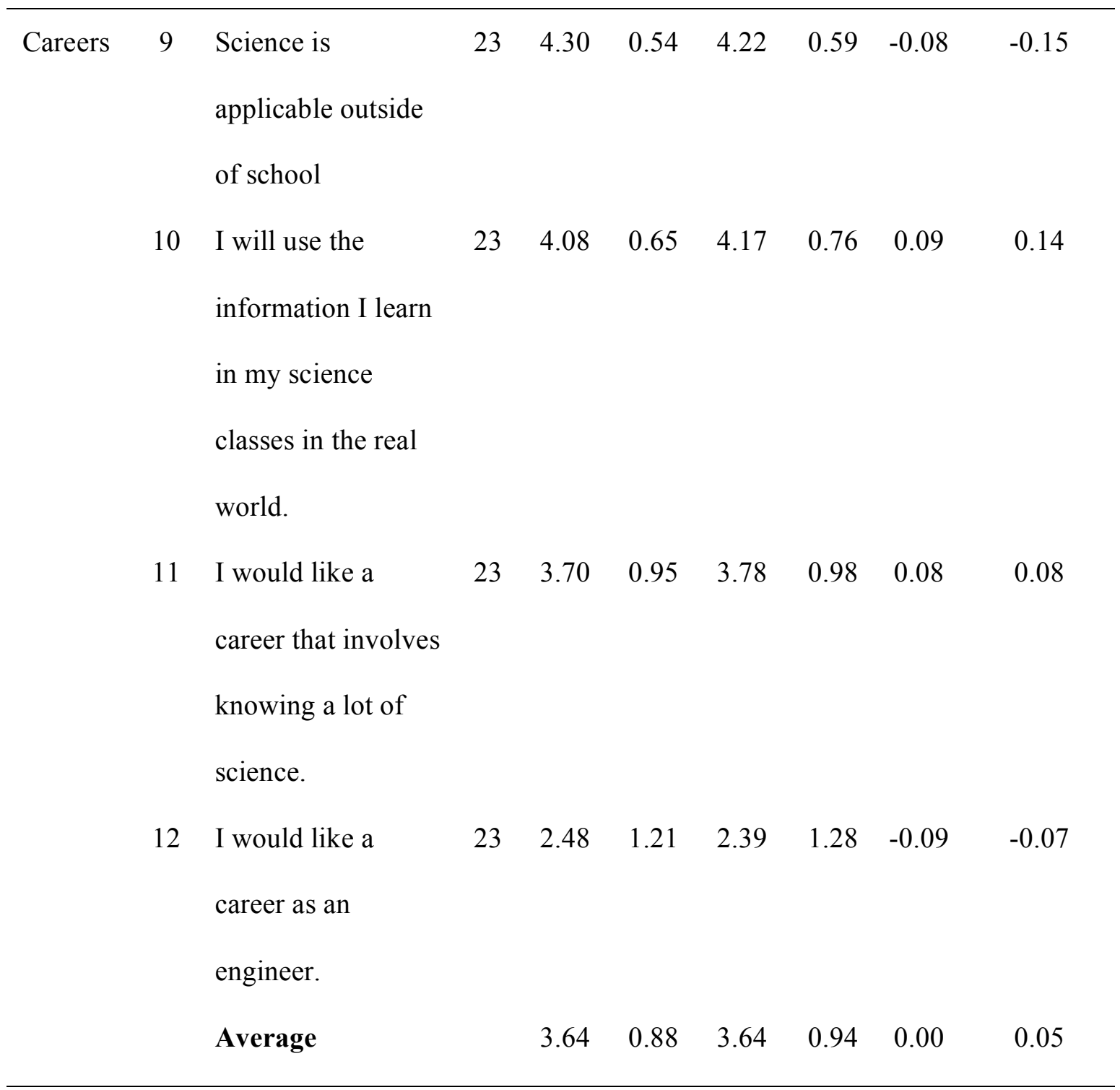




\section{Pre- and Post-survey Comparison of Data for Learning and Assessment Preference Data}

Data was collected in a pre-survey and post-survey to analyze any learning preference changes that resulted from the implementation of project-based learning. Additionally, the pre- and post-survey data was used to determine if students had a change in preference in portfolio-based assessment versus traditional test assessments.

Effect Size. The results of changes in learning preferences are shown in Table 9. Raw data used to produce the mean and standard deviation in these tables can be found in Appendix E. The effect size was calculated for the learning and assessment preferences of students in Table 9 . 
Table 9. Effect Size for Pre- and Post-Survey Change in Preference of Students.

\begin{tabular}{|c|c|c|c|c|c|c|c|c|c|}
\hline \multirow[b]{2}{*}{ Part } & \multirow[b]{2}{*}{ No. } & \multirow[b]{2}{*}{ Statement } & \multirow[b]{2}{*}{$\mathbf{N}$} & \multicolumn{2}{|c|}{ Presurvey } & \multicolumn{2}{|c|}{ Postsurvey } & \multirow[b]{2}{*}{ Diff. } & \multirow{2}{*}{$\begin{array}{c}\text { Effect } \\
\text { size }\end{array}$} \\
\hline & & & & Mean & SD & Mean & SD & & \\
\hline \multirow[t]{10}{*}{ Portfolio } & 13 & I would prefer & 23 & 3.39 & 1.09 & 3.48 & 1.17 & 0.09 & 0.08 \\
\hline & & my teachers & & & & & & & \\
\hline & & assess my & & & & & & & \\
\hline & & achievement & & & & & & & \\
\hline & & through & & & & & & & \\
\hline & & portfolios & & & & & & & \\
\hline & & rather than & & & & & & & \\
\hline & & end of the unit & & & & & & & \\
\hline & & or chapter & & & & & & & \\
\hline & & tests. & & & & & & & \\
\hline \multirow{12}{*}{$\begin{array}{l}\text { Learning } \\
\text { Preferences }\end{array}$} & 14 & I learn best & 23 & 2.87 & 1.36 & 3.13 & 0.99 & 0.26 & 0.19 \\
\hline & & when I find & & & & & & & \\
\hline & & information on & & & & & & & \\
\hline & & my own or & & & & & & & \\
\hline & & self-teach. & & & & & & & \\
\hline & 15 & I learn best & 23 & 3.34 & 1.12 & 3.30 & 1.15 & -0.04 & -0.04 \\
\hline & & when & & & & & & & \\
\hline & & information is & & & & & & & \\
\hline & & presented to & & & & & & & \\
\hline & & me in a & & & & & & & \\
\hline & & lecture-style & & & & & & & \\
\hline & & format. & & & & & & & \\
\hline
\end{tabular}

table continued 
Table 9 (continued).

\begin{tabular}{|c|c|c|c|c|c|c|c|c|}
\hline 16 & $\begin{array}{l}\text { I learn best } \\
\text { through } \\
\text { hands-on } \\
\text { activities. }\end{array}$ & 23 & 2.91 & 0.88 & 3.08 & 1.02 & 0.17 & 0.19 \\
\hline 17 & $\begin{array}{l}\text { I prefer } \\
\text { learning by } \\
\text { doing projects. }\end{array}$ & 23 & 3.39 & 1.2 & 3.22 & 1.24 & -0.17 & -0.14 \\
\hline 18 & $\begin{array}{l}\text { I prefer } \\
\text { learning by } \\
\text { doing group } \\
\text { work. }\end{array}$ & 23 & 3.39 & 1.58 & 3.30 & 1.12 & -0.09 & -0.06 \\
\hline 19 & $\begin{array}{l}\text { I prefer } \\
\text { learning by } \\
\text { doing book } \\
\text { work. }\end{array}$ & 23 & 2.78 & 1.06 & 2.70 & 0.91 & -0.08 & -0.08 \\
\hline 20 & $\begin{array}{l}\text { I prefer } \\
\text { learning } \\
\text { through lab } \\
\text { experiences. }\end{array}$ & 23 & 3.48 & 1.25 & 2.83 & 1.13 & -0.65 & -0.52 \\
\hline & Average & & 3.17 & 1.21 & 3.08 & 1.10 & -0.09 & -0.07 \\
\hline
\end{tabular}




\section{Questionnaire Results}

Input data was also evaluated from a student questionnaire. This questionnaire had a Likert scale rating the overall project from 1 being "Terrible" to 5 being "Great." The data for this scale is found in Table 10. The questionnaire posed four questions to which students were able to give feedback on. The students commented on what they liked most and least about the project. They also stated why they preferred the portfolio assessment over a traditional test assessment or vice versa. Lastly, the students commented on if they had a better understanding of what an engineer does and what they think their job description is.

\section{Table 10. Mean and Standard Deviation for Student Questionnaire Results From Project Ranking}

\begin{tabular}{lccc}
\hline Question & N & Mean & SD \\
\hline Overall, how would you rate this project? & 23 & 2.87 & 1.08 \\
\hline
\end{tabular}

Table 11 gives a summary of student responses to the questionnaire. It should be noted that some students gave more than one comment for each question. 
Table 11. Student Questionnaire Feedback

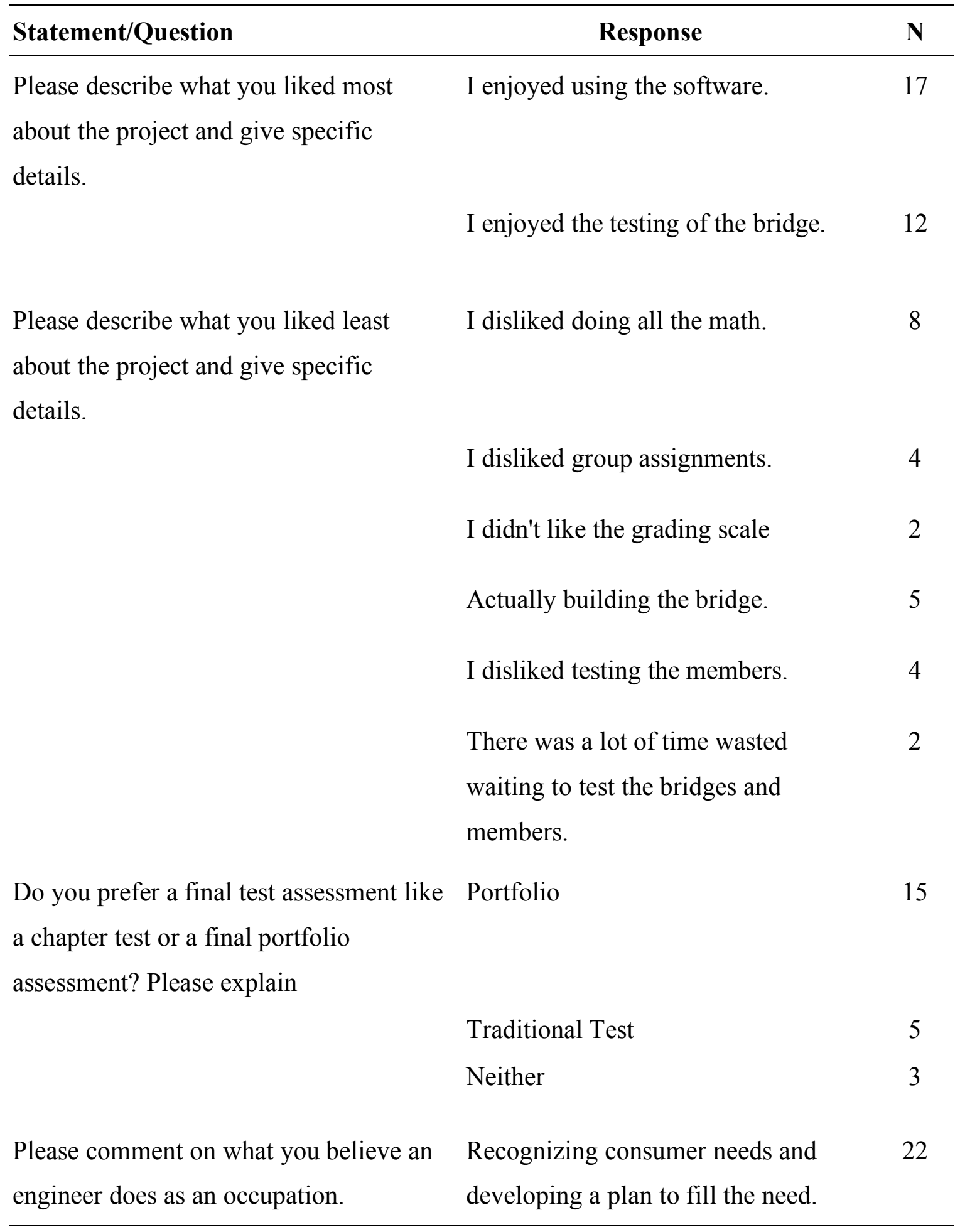




\section{Portfolio Assessment}

Michigan Content Expectations were incorporated into this project-based experience. Through the portfolio, students were able to address several core and essential content standards as mentioned in Chapter 2. These standards were assessed when students showed understanding of concepts not by creating a bridge that did or did not work, but by explaining how the bridge did or didn't work. The students described what components of the bridge worked and what failed. In addition, students explained why their bridge was or wasn't efficient. They also reflected on their work and stated how they could improve their bridges by applying their knowledge of physics concepts.

A grading rubric was developed and given to the teams before the start of the project. The grading rubric can be found in Appendix A. A table of the HSCEs and where they were assessed in the rubric is found in Table 12. 
Table 12. HSCEs Assessed in Grading Rubric

\begin{tabular}{lc}
\hline Rubric Item & HSCE \\
\hline Overview of need statement & P1.1A; P1.1C \\
Overview of tension/compression tests & P1.1C \\
Member Assessment: Tensile Strength & P1.1A; P1.1C; P1.1E \\
Member Assessment: Compression Strength & P1.1A; P1.1C; P1.1E \\
Member Assessment: Analysis of Results & P1.1B; P1.1g; P1.1h \\
Questions from Activity 1 (1-10) & P3.1A; P3.2A; P3.2C; P3.4C \\
Bridge Proposal: Analysis of internal forces of & P3.1A; P3.2A; P3.2C; P3.4C; \\
bridge & G1.3.1 \\
Bridge Proposal: Prediction of Failure & P1.1g; P1.1h; P3.2A \\
Bridge Proposal: Analysis of actual failure & P1.1B \\
Questions from Activity 5 (1-4) & P3.1A; P3.2A; P3.2C; P3.4C; \\
& G1.3.1 \\
Conclusion: What would your company do in & P1.1B; P1.1E \\
order to earn the job in the future? & \\
\hline
\end{tabular}


Understanding was determined by the ability to communicate the relationships between knowledge and how it applied to building their bridge. The students' portfolios were assessed and grouped into a region of understanding that was created by the researcher. If the student received an $86 \%$ or higher on their portfolio they were considered to have a high level of understanding, 85-80 was considered adequate understanding, 79-70 was considered a level of some understanding, 69-60 was considered little understanding and 59-0 was considered little to no understanding. These percentages are aligned with the districts designated grading scale, where $86 \%$ and above is considered proficient, $85-80$ is above average, 79-70 is average, 69-60 is below average and 59-0 is failing. Table 13 shows the students' portfolio grades scores.

\section{Grading}

The rubric for the bridge grade (Appendix D) broke the grade down into components of the bridge score, if the bridge was built and in on time, whether the bridge was determinant, and whether or not the bridge held under the load for 30 seconds.

The portfolio was grading using the portfolio grading rubric (Appendix A). Emphasis was put on the testing of the member components, students' rationale for design decisions, and application of trigonometry to determine the forces present in each member of the bridge.

The total weighted grade for the project was split into the portfolio grade and the bridge itself. All teams were graded as a group and received a group score. The portfolio was worth $90 \%$ and the bridge was worth $10 \%$ of the total grade. As stated previously, I wanted the emphasis of this project to be based on the rationale of the students' decisions 
and work rather than the bulk of the points on the completion of the bridge. I found this to be of greater importance than actually getting the "right answer." This was a philosophy that I used in all assessments during the school year.

Table 13 shows the groups' bridge grades, portfolio grades, and total weighted grades. 


\section{Table 13. Students' Grades}

\begin{tabular}{cccc}
\hline Group number & Portfolio Grade & Bridge Grade & Total Weighted Grade Earned \\
\hline 1 & 83.9 & 83.3 & 83.8 \\
2 & 87.7 & 83.3 & 86.8 \\
3 & 100 & 88.9 & 97.8 \\
4 & 89.9 & 77.8 & 87.5 \\
5 & 94.3 & 83.3 & 92.1 \\
6 & 96.7 & 77.8 & 92.9 \\
7 & 95.63 & 77.8 & 92.1 \\
8 & 56.8 & 94.4 & 64.4 \\
Average & 88.1 & 83.3 & 87.2 \\
\hline
\end{tabular}

Note: Bridge Grade $=10 \%$ and Portfolio Grade $=90 \%$ of Total Grade 


\section{Comparison to Previous Grades}

Prior to the implementation of the project, students were assessed with traditional chapter tests. Three chapter tests occurred prior to the implementation of this project. These grades were included to compare the grades of a traditional assessment with the final portfolio assessment. The mean scores of these tests are found in Table 14.

Table 14. Traditional Chapter Test Mean Scores

\begin{tabular}{cc}
\hline Test & Average Score \\
\hline Chapter 1 & 87.3 \\
Chapter 2 & 84.3 \\
Chapter 3 & 88.1 \\
Average & 86.6 \\
\hline
\end{tabular}




\section{Chapter 5-Discussion}

I wanted to determine if students' attitude toward science and related careers, as well as, learning and assessment method preferences could be changed using projectbased learning and portfolio assessments. The research showed using project-based learning activities had some mixed results on students' attitude toward science. While students showed a slight positive change in attitude toward science, they had a negative change in attitude towards physics. Additionally, these project-based activities showed a slight positive change in the student's preference hands-on activities and a negative change in preference to lab activities. The data also show students' attitude toward portfolio assessment improved after implementing this assessment. The most useful tool for me was the student questionnaire because students were able to explain their feelings towards the variables measured in this action research.

\section{Analysis of Findings on Student Attitude Toward Science}

The data collected from student surveys was used to answer the question: In what way would the implementation of a project-based activity affect the students' attitude toward science and physics? From this main question, a sub-question was produced pertaining to student attitudes. This question was: To what extent will students' interests in science related careers like engineering change?

In what way would the implementation of a project-based unit change the attitude towards science and physics? The attitudes portion of the survey was 
analyzed in two parts. The first portion was attitude towards science; the second portion was attitudes towards careers. The data in Table 8 shows the changes in attitude towards science and physics. Statements 1- 8 pertained to their attitudes towards science. Results did not show a change in attitude toward science. The overall effect size of this portion of the survey was -.07 , which is deemed as a chance occurrence and not of importance.

When looking at the individual results more closely, there was a slight increase in the score of the statements "I like science" and "Science is fun." These statements had an effect size of .11 and .13, respectfully. With this effect size, the changes are considered to be of some importance. The statement "Science is boring" also had an effect size of .41. This means, less students agreed with the statement "Science is boring." This is possibly an important change in the students' attitudes.

One other change in attitude was that more students disagreed with the statement "I like physics." The effect size from this statement was -.28. This falls within the practically significant effect size as stated by Bracey (2000).

\section{To what extent will students' interest in science related careers like} engineering change? The second portion of the attitudes survey had statements that pertained to careers and real-world relevancy. The average effect size for this portion was .05 (Table 8).

Students rated the statement "I will use the information I learn in my science classes in the real world" more highly in the post survey. The effect size from this statement was .14. However, students rated the statement "Science is applicable outside of school" lower in the pre-survey. The effect size was -.15 . Students responded to the statement "I would like a career that involves knowing a lot of science" more highly in 
the post-survey. The average effect size was .08. However, the students rated the statement "I would like a career as an engineer" lower in the post-survey. The effect size of this statement was -.07 .

In general, there was little change in the responses between the student presurvey and post-survey results.

\section{Analysis of Findings on Student Preferences}

The second part of the survey was developed to address the sub-questions: Two sub-questions evolved from the second research question: To what extent did a projectbased assignment change the learning preferences of the students? Do students prefer portfolio assessments rather than traditional assessments?

\section{To what extent did the project-based assignment change the learning} preference of the students? Table 9 shows the second part of the survey, which concerned the learning preferences of students, as well as the portfolio assessment preference. The effect size for this portion of the survey was -.07 . When analyzing the individual statement results, both learning by self-teaching and hands-on activities showed a positive change with an effect size of .19 each. While bookwork, group work and lecture all showed a negligible change in effect size. The effect size from learning through doing projects showed a negative change of -.14. This was considered to be of some importance. Students' response to "I prefer learning through lab activities" had an effect size of -.52. This change may be of some importance. 


\section{Do students prefer portfolio assessments rather than traditional}

assessments? Table 9 shows the results for the preference towards portfolio

assessment. The effect size of this statement was .08. This is considered to be negligible.

\section{Will students be able to demonstrate understanding using a portfolio?}

One question that was developed in the research was: Will students be able to demonstrate their understanding of applied physics concepts using a portfolio assessment?

Students demonstrated their ability to rationalize their understanding of physics in the portfolios. Table 12 shows where the HSCEs are assessed in the portfolio. The bulk of the point values were earned in the rationale behind their decisions.

The teams' grades are presented in Table 13. The overall average on the portfolios was 88.1. This is considered proficient. All of the groups were considered to be of "understanding" to "high understanding" except for one group. This group earned a score of no proficiency. After reading the student questionnaires, this was due to a lack of organization and communication from the teammates. The portfolio this team turned in had many missing portions.

Test scores from traditional chapter tests were listed in Table 14. The tests show an average score of 86.6. There was very little change in the average performance when comparing the average of these traditional assessments to the portfolio assessment. 


\section{Student Feedback from Questionnaire}

A questionnaire was collected from the students after they turned in the day they turned in their portfolios. The questionnaire was designed to give me feedback to improve the project in the future. The questionnaire also gave me a better understanding of why some students did or did not like the project and portfolio assessment. The student comments were summarized in Table 11.

The most common remarks to the question "Please describe what you liked most about the project and give specific details" was that students enjoyed using the West Point Bridge Builder Software to design their bridges and the actual testing of the bridges. Out of the 23 students tested, 17 remarked that they enjoyed the software and 12 enjoyed the testing most. Some students had more than one activity they liked most.

The feedback to the statement "Please describe what you liked least about the project and give specific details" was not as biased as to the first questionnaire statement. Answers varied from not liking group assignments, the grading scale, the bridge building, member testing, and the wait for testing the members and bridges. Eight of the 23 students commented that they did not like doing the math.

Students' comments on the third question "Do you prefer a final test assessment like a chapter test or a final portfolio assessment? Please explain" resulted in 15 in favor of the portfolio, 5 in favor of a final test and three that commented that they would rather do neither. Comments from students that preferred the portfolio were that it was easier to split up the work within the group and could pace themselves. Explanations from students who preferred a test assessment were that it would be one day of studying 
instead of weeks of preparing a portfolio, it was too much work to do the portfolio, and the student would have more control over their grades rather than relying on teammates.

The last question was "Do you have a better understanding of what an engineer does after doing this project? Please comment on what you believe an engineer does." Students' comments included recognizing customer needs and developing a costeffective way to fill the need. Interestingly, 6 people wrote that they had to deal with more stress than engineers because of their team members not coming through or their bridge not working the way they had predicted it would. Two students mentioned they felt they already had a good idea of what an engineer did prior to the implementation of this project. 


\section{Chapter 6-Conclusion and Implications}

\section{Conclusions on Student Attitude Towards Science}

Based on the surveys, there was minimal change in the students' attitudes towards science. There was a notable change in the attitude towards physics. I believe this is due to the project being a bit overwhelming. Students commented on how long it took to build bridges and create the portfolio. There were also frustrations with the math involved in determining the internal forces in the members of the truss bridge.

Another noteworthy response in the survey is less students agreed with the statement science is boring. Additionally, more students agreed with the statement "Science is fun" and "I like science." I believe this change may have been due to the enjoyment of testing the bridges and seeing the final product work. One student commented "I felt a sense of accomplishment... when my bridge actually held the weight." Prior to building the bridges, I let students hold the bucket with the $6 \mathrm{~kg}$ of sand in it. Students expressed that they didn't think the file folder material would hold up under the weight because of how heavy the bucket felt.

Interestingly, the student results from the survey showed students thought science was important and applicable in the real world; however their attitude towards science decreased. These results may imply that students have the impression that science is going to be important and applicable in the real world, however, that doesn't mean they have to like it. These highly motivated students may understand that they will need science as part of their education to be successful and cope in the real world. 


\section{Conclusions on Student Attitude Towards Engineering}

Although there was a negligible change in the students' interest in engineering, it should be noted that in conversations with students, there were three who said they were definitely interested in engineering and two students who said they would consider engineering as a career field. However, there were four students who had been considering engineering as a career field who had decided they would not be pursuing it as a career. In conversation, they said they didn't like how much math was involved in engineering.

It should be noted that some of the results of the survey contradicted each other. Although more students agreed with the statement "I will use the information I learn in my science classes in the real world", less students agreed with the statement "Science is applicable outside of school". It is unclear to me why students would not agree more with the statement "Science is applicable outside of school" after they witnessed the application of the distribution of forces in the truss bridge. My expectations were that students would find science more applicable by understanding how forces were distributed through a bridge truss.

\section{Conclusions on Learning Preferences}

There were some changes in learning preferences that are somewhat alarming. Students' response to "I prefer learning through lab activities" had a notable change in effect size. I did give an explanation to the students that a lab activity was one that had 
instructions for an activity that students would know an expected outcome of the lab. It is possible that students confused projects and lab activities.

The statement "I learn best when I find information on my own or self-teach" had a change of .19. I feel some of the reasons more students agreed with this statement was the negative experience some students had with their group members, particularly the group that earned a $56.8 \%$. These students each rated their level of agreement with this statement as strongly agree. However, in the post-survey, these students rated this statement with a strongly disagree and two disagrees.

\section{Conclusions on Portfolio Assessment}

While students performed comparably in the portfolio assessments as in traditional assessments, there is question whether or not the students could accomplish the tasks from the portfolio in a more traditional test. In my own observations, the lessons did not carry over into later lessons. It was my hope that the method of joints, a component vector analysis method, would easily be related to the future lessons. However, this was not the case when using vector component analysis in successive chapters. As a result, I had to go back and teach students how to determine the resulting vectors from component vectors. I believe this is due to the responsibilities set in each group when completing the portfolios. Many groups chose to split of up the work where one group member ended up doing the math portion of the project. Although I forewarned the students that they would all be responsible for knowing the method of joints analysis, many admitted they did not learn it. 
Students commented both positively and negatively in regards to portfolio assessments. Student comments included, "The portfolio gave me a chance to contribute to what I was good at and get help with things I was not good at." This type of cooperative learning can be beneficial to students as long as the team members help each other develop those weaker aspects.

One student commented, “I didn't like the portfolio because I could have studied for one hour to prepare for a test." Another student commented that the portfolio took a "combined effort of 22 hours to complete" by the group members.

When comparing the traditional tests from previous chapters, the average mean of the tests was comparable to the mean from the portfolio assessments. This may give some validity to the use of portfolios as an assessment tool for students.

As a compromise between portfolio assessments and traditional learning, a traditional test will accompany the portfolios in order to lay more responsibility on the students to learn the method of joints analysis. This would also give students the opportunity to learn cooperatively, as well as, give students more personal control over their grades rather than solely relying on other group members.

As in Yildirim's (2004) research, most of my students rarely avoid work because achievement is a top priority to them. They are used to doing the work themselves in order to reach their target GPA. I anticipated some students would be reluctant to work with groups. Comments from the student questionnaire confirmed my suspicion that some students would not like the portfolio and project because less time is generally spent for test preparation. Also, students would only have to rely on themselves to achieve passing grades rather than on teammates. 


\section{Changes for Future Research}

This project was the first project-based activity done in this physics class. As the year progressed, more project-based units were implemented. I observed that students did warm up to project-based learning toward the end of the year. Had I surveyed students later in the year, I would have had better data with which to compare my preand post-survey data to. Students seemed to warm up to a more project-based curriculum. It should be noted that the other projects implemented within the school year were not quite as intense. The timeline for these projects was a week to a week and a half in length. Additionally, I did not use formal portfolio assessments in the other projects. Rather, portions of the portfolio criteria were used in conjunction with regular chapter test. For instance, during the unit on electricity, students had to develop a plan to restore a historic home's wiring. The students used the engineering process to fill a need for an imaginary customer. They also had to discuss in detail the rationale for the decisions made through the engineering process. In addition to the devised plan, students were also tested. In the testing, students were required to solve mathematical problems similar to problems that were involved in filling the need. This was to ensure accountability of students.

The group that scored a $56 \%$ on the portfolio made me think critically about the need to develop other assessments in addition to portfolios. This group professed they did not organize themselves well and had a lack of communication amongst group members. As a result, there were large sections of the portfolio that were not complete. This did not mean the students didn't necessarily understand the material; rather they had poor teamwork skills for this project. This could be contributed to the validity of the 
portfolio. As stated previously, additional traditional assessments will accompany group portfolios so that students have more control over their grades.

\section{Implications of Research}

One goal of this research was to improve student attitude towards physics through project-based lessons. It is my opinion that this project was a bit overwhelming for students. I believe the time-intensive bridge building and quantity included in the portfolio were major contributors to this change in attitude towards physics. In the future, the scale of the portfolio will be minimized so that it isn't as overwhelming and a traditional test will be implemented.

I was hoping this research would show students' attitudes overwhelmingly change in favor of project-based education and a positive change in the attitudes of students towards science in order to use the data to show how influential PBL can be. However, the results of this research did not show this. I believe this can be contributed to the fact that PBL is not a learning style that my students were accustomed to. After some reflection, I began to think of this as a way to further research in PBL education in the district. I feel for a project-based unit like this to be successfully implemented projectbased education cannot be introduced at the junior or senior level. It is my goal for the Elk Rapids School District curriculum committee to research and possibly implement PBL within the district's science department.

With the recent development of the Michigan Grade Level Expectations (GLCEs) there will be opportunities for professional and curriculum development and possibly more research in the area of PBL at the elementary and middle school level. 
Because I serve on the districts' curriculum committee, I can share my findings from this research and try to develop some interest within the department in PBL. 
(This page deliberately blank) 


\section{References}

Barrett, H. (n.d.). A Chapter in Educational Technology. In Electronic portfolios.

Retrieved March 16, 2007, from

http://electronicportfolios.com/portfolios/encyclopediaentry.htm

Beers, G. W., EdD, RN., \& Bowden, S., MSN, RN. (2005, November). The Effect of Teaching Method on Long-Term Knowledge Retention [Electronic version]. Journal of Nursing Education, 44(11), 511-514.

Bracey, G. W. (2000). Chapter 13: Differentiate Practical and Statistical Significance. In Bail Me Out!: Handling Difficult Data and Tough Questions About Public Schools (pp. 58-62). California: Corwin Press, Inc.

Chinowsky, P. S., Brown, H., Szajnman, A., \& Realph, A. (2006, April). Developing knowledge landscapes through project-based learning. Journal of Professional Issues in Engineering Education and Practice, 132(2), 118-124.

Dochy, F., Segers, M., \& Sluijsmans, D. (1999). The use of self- peer- and co-assessment in higher education: a review [Electronic version]. Studies in Higher Education, 24(3), 331-350.

Ellis, G. W., Scordilis, G. E., \& Cooke, C. M. (2003, November). New Pedagogical Approaches in Engineering Mechanics Yield Increased Student Understanding, Confidence, and Committment [Electronic version]. ASEE/IEEE Frontiers in Education Conference, t4a15-t4a20.

Gable, R. K., \& Wolf, M. B. (December 1993). Instrument Development in the Affective Domain. Measuring Attitudes and Values in Corporate and School Settings (2nd ed.). Boston: Springer. 
Gallagher, J. T. (2000, October). Teaching for Understanding and Application of Science Knowledge [Electronic version]. School Science and Mathematics, 100(6), 310318.

Gülbahar, Y., \& Tinmaz, H. (2006, Spring). Implementing Project-Based Learning and E-Portfolio Assessment in an Undergraduate Course [Electronic version]. Journal of Research on Technology in Education, 38(3), 309-327.

Hays, R. B. (2004). Reflecting on learning portfolios [Electronic version]. Medical Education, 38, 800-804.

Helle, L., Tynjala, P., \& Olkinuora, E. (2006). Project-based learning in post-secondary education- Theory, practice and rubber sling-shots [Electronic version]. Higher Education, 51, 287-314.

Knight, M., Huttlinger, C., Carlson, B., \& Cunningham, C. (2006, October). Engineering in the Classroom [Electronic version]. The Technology Teacher, 18-21.

Kubler-LaBoskey, V. (2000, April). Portfolios Here, Portfolios There...Searching for the Essence of "Educational Portfolios" [Electronic version]. Phi Delta Kappan, 590595.

Liu, M., Hsieh, P. P.-H., Cho, Y., \& Schallert, D. (2006, July). Middle school students' self-efficacy, attitudes, and achievement in a computer-enhanced problem-based learning environment [Electronic version]. Journal of Interactive Learning Research, 17(3), 225-242.

Lutz, F. C., \& Schachterle, L. (1996). Projects in Undergraduate Engineering Education in America [Electronic version]. European Journal of Engineering Education, 21(2), 207-214. 
Lynch, L., \& Purnawarman, P. (2004). Electronic portfolio assessment in U.S. educational and instructional technology programs: Are they supporting teacher education? . TechTrends, 48(1), 50-56.

Michigan State Board of Education. (2006). Michigan High School Content Expectations. Retrieved Fall, 2006, from http://www.michigan.gov/mde/0,1607,7-14038924_41644_42814---,00.html

Nickelson, D. (2004, April). Portfolios in Physics [Electronic version]. The Science Teacher, 71, 52-55.

Railsback, J. (2002). Project-based Instruction: Creating Excitement for Learning [Electronic version]. By Request, 3-58.

Ressler, S. J., P.E., Ph.D. (2002). Chapters 1, 2, 4, 5. In Designing and Building FileFolder Bridges (pp. 1-1-2-28, 4-1-5-24). West Point, NY: Author.

Serway, R. A., \& Faughn, J. S. (n.d.). Holt Physics. (Reprinted from Holt Physics, pp. 124-157, 2002, Austin: Holt, Rinehart and Winston)

Shaver, J. P. (1985, September). Chance and Nonsense: A Conversation About Interpreting Tests of Statistical Significance, Part 1. Phi Delta Kappan, 57-60.

Shaver, J. P. (1985, October). Chance and Nonsense: A Conversation About Interpreting Tests of Statistical Significance, Part 2. Phi Delta Kappan.

Sigler, E. A., \& Tallent-Runnels, M. K. (2006). Examining the validity of scores from an instrument designed to measure metacognition of problem solving [Electronic version]. The Journal of General Psychology, 133(3), 257-276.

Standard \& Poors. (n.d.). School Matters. Retrieved July 17, 2007, from School Matters database: http://www.schoolmatters.com 
Sungur, S., Tekkaya, C., \& Geban, O. (2006, August). Improving achievement through problem-based learning [Electronic version]. Journal of Biological Education, 40(4), 155-160.

Symans, M. D. (2000, July). Introducing middle school students to engineering principles using educational bridge design software. Journal of Engineering Education, 273278.

Teubert, A. R. (September 8, 2006). The Effect of an Inquiry-Based Curriculum and Experiential Education on Middle School Students' Attitude in Science [Data file]. Retrieved from J. Robert Van Pelt Library Online Catalog database: http://sunshine.lib.mtu.edu/ETD/THESIS/2006/Education/teuberta/report.pdf

Tigelaar, D. E., Dolmans, D. H., Wolfhagen, I. H., \& van der Vleuten, C. P. (2005, October). Quality issues in judging portfolios: Implications for organizing teaching portfolio assessment procedures [Electronic version]. Studies in Higher Education, 30(5), 595-610.

The West Point Bridge Designer (Version 10.0.0) [Computer software and manual]. (2007). Retrieved January 4, 2007, from http://bridgecontest.usma.edu/download.htm

Wolf, A. (1998). Portfolio Assessment as National Policy: The National Council for Vocational Qualifications and Its Question for Pedagogical Revolution. Assessment in Education, 5(3), 413-445.

Yildirim, Z. (2004, April 15). On-line submission. In Relationship between Achievement Goal Orientation and Collaboration in Project-Based Learning Process. Retrieved November 22, 2006, from ERIC database: http://www.eric.ed.gov 


\section{Appendix A}

\section{Portfolio Rubric}


(This page deliberately blank) 


\section{Rubric for File Folder Bridges}

Note: Please start your portfolio at the beginning of this unit. DO NOT leave it to the weekend before it is due. There are many portions of the portfolio that can be completed along the way. If you have any questions about what is required of your team, please ask.

\section{/189 Portfolio Assessment}

15_ Table of Contents

List all contents with all page numbers

120 Introduction - addresses the point of the project

$\circ \quad / 10$ Why did you build the bridge

- Give an overview of the need statement for the project and the objectives you had to building the bridge.

$\circ \quad / 10$ An overview of the steps you took that lead to the completion of the project.

- What questions must you consider when developing your bridge? Example: What kind of glue should I use to make my bridge light and still hold it all together? How can I make the most cost-effective bridge?

- Include why you tested the members' strength

- What the purpose of the West Point program was

/63 Member Assessment

○ Tensile strength

15 Give an overview of the purpose of this part of the project 
- Include why you tested the members' strength

- What were some questions generated through this experiment?

13 Include your prediction for the relationship between tension member length vs. strength and width vs. strength. Use your original prediction!!!

/6 Include your data in a table and graph

16 Include the class data in a table and graph

○ Compression strength

15 Give an overview of the purpose of this part of the project

13 Include your prediction for the relationship between compression member length vs. strength and width vs. strength. Use your original prediction!!!

/6 Include your data in a table and graph

/6 Include the class data in a table and graph

- Analysis of Results

13 Discuss results of the tension and compression tests. Include discussion of the outliers, general trends, etc in data.

13 Compare your data with the expected outcomes found in your packets.

13 How did you use this information in building your bridge?

Q Questions from the end of the handout

/14 (1-10) Activity 2: Pg 8, 10, 17-19, 21, 23, 25

$/ 71$ Bridge proposal 
- Schematics of bridge

110 Size of the members and number needed

List each size

- Ex: $7-10 \mathrm{~mm} \times 10 \mathrm{~mm} \times 10 \mathrm{~cm}$ hollow members in truss

- Don't forget gussets.

- Analysis of internal forces of bridge

130 All of the math you did to find the internal member forces

- Please clearly label and make it super-dooper organized and neat

$\circ$ Drawings of bridge - the big poster

/10 Orthographic

- Front (truss)

- $\quad$ Side (looking down roadway)

- Top

- Bottom

- Scoring of bridge

$13 \mathrm{~L} * \mathrm{C} * \mathrm{~m}=$

○ Prediction of bridge failure - specifically which numbered member(s)?

/5 Rationale behind your prediction.

- Use the forces you found from calculations.

- Explain what type of member it was $(\mathrm{C}$ or $\mathrm{T})$.

The math is the only portion of the portfolio that may be written. 
- Actual Analysis of Failure

15 State where the bridge actually failed and your rationale as to why it failed there.

- Questions from the packet

/8 (1-4) Activity 5: pg 10, 12, 13, 22

ㄴ $\quad$ /20 Conclusion

$\circ \quad 15$ Who got the job

- Based on the lightest bridge

- Held the $59 \mathrm{~N}$ for 30 seconds

$\circ \quad 15$ Why did or didn't your company get the job?

- What factors kept you from having the lightest, structurally sound bridge?

$\circ \quad / 10$ What would your company do in order to earn the job in the future?

- Specifically, how would you modify your bridge?

- EX: Don't just say, "We would make our bridge lighter." What specific changes would you make to design or construct a lighter bridge?

- Rationalize your changes

- That is, explain why you would make the changes proposed in the previous bullet.

- Example: How would you make the bridge lighter and still maintain structurally sound components? 
- Hint: How can you use the information you learned in Activity 2 to help make some changes?

a 110 Aesthetics

$\circ \quad 15$ Portfolio

- Is it put together well, organized, type-written, etc?

○_ _ 15 Grammar, punctuation, spelling, complete sentences (Will I know what the question is by reading your answer?), etc

\section{/19 Bridge assessment}

- Stability and determinacy

- Holds $6 \mathrm{~kg}$ for 30 seconds

- Lowest score not equal to zero

- Meets requirements for dimensions

a Finished and in on time

\section{Group assessment}

- You will evaluate your co-workers

Their assessment may be used to assist in your final project grade. 
(This page deliberately blank) 
Appendix B

Student Survey 
(This page deliberately blank) 


\section{Student Survey}

Circle the option that best describes your level of agreement with the statement. Student Number

\begin{tabular}{|c|c|c|c|c|c|c|}
\hline & Statement & & & Level of Agreemen & & \\
\hline 1 & I like science. & $\begin{array}{l}\text { strongly } \\
\text { agree }\end{array}$ & agree & $\begin{array}{l}\text { neither agree nor } \\
\text { disagree }\end{array}$ & disagree & $\begin{array}{l}\text { strongly } \\
\text { disagree }\end{array}$ \\
\hline 2 & Science is fun. & $\begin{array}{l}\text { strongly } \\
\text { agree }\end{array}$ & agree & $\begin{array}{l}\text { neither agree nor } \\
\text { disagree }\end{array}$ & disagree & $\begin{array}{l}\text { strongly } \\
\text { disagree }\end{array}$ \\
\hline 3 & I am good at science. & $\begin{array}{l}\text { strongly } \\
\text { agree }\end{array}$ & agree & $\begin{array}{l}\text { neither agree nor } \\
\text { disagree }\end{array}$ & disagree & $\begin{array}{l}\text { strongly } \\
\text { disagree }\end{array}$ \\
\hline 4 & Science is boring. & $\begin{array}{l}\text { strongly } \\
\text { agree }\end{array}$ & agree & $\begin{array}{l}\text { neither agree nor } \\
\text { disagree }\end{array}$ & disagree & $\begin{array}{l}\text { strongly } \\
\text { disagree }\end{array}$ \\
\hline 5 & $\begin{array}{l}\text { Learning about science is } \\
\text { important. }\end{array}$ & $\begin{array}{l}\text { strongly } \\
\text { agree }\end{array}$ & agree & $\begin{array}{l}\text { neither agree nor } \\
\text { disagree }\end{array}$ & disagree & $\begin{array}{l}\text { strongly } \\
\text { disagree }\end{array}$ \\
\hline 6 & I like physics. & $\begin{array}{l}\text { strongly } \\
\text { agree }\end{array}$ & agree & $\begin{array}{l}\text { neither agree nor } \\
\text { disagree }\end{array}$ & disagree & $\begin{array}{l}\text { strongly } \\
\text { disagree }\end{array}$ \\
\hline 7 & $\begin{array}{l}\text { I like taking part in } \\
\text { science-related activities } \\
\text { outside of school (i.e.: } \\
\text { clubs, science kits, etc) }\end{array}$ & $\begin{array}{l}\text { strongly } \\
\text { agree }\end{array}$ & agree & $\begin{array}{l}\text { neither agree nor } \\
\text { disagree }\end{array}$ & disagree & $\begin{array}{l}\text { strongly } \\
\text { disagree }\end{array}$ \\
\hline 8 & $\begin{array}{l}\text { I like to watch science } \\
\text { programs like the ones on } \\
\text { Discovery Channel. }\end{array}$ & $\begin{array}{l}\text { strongly } \\
\text { agree }\end{array}$ & agree & $\begin{array}{l}\text { neither agree nor } \\
\text { disagree }\end{array}$ & disagree & $\begin{array}{l}\text { strongly } \\
\text { disagree }\end{array}$ \\
\hline 9 & $\begin{array}{l}\text { Science is applicable } \\
\text { outside of school }\end{array}$ & $\begin{array}{l}\text { strongly } \\
\text { agree }\end{array}$ & agree & $\begin{array}{l}\text { neither agree nor } \\
\text { disagree }\end{array}$ & disagree & $\begin{array}{l}\text { strongly } \\
\text { disagree }\end{array}$ \\
\hline 10 & $\begin{array}{l}\text { I will use the information } \\
\text { I learn in my science } \\
\text { classes in the real world. }\end{array}$ & $\begin{array}{l}\text { strongly } \\
\text { agree }\end{array}$ & agree & $\begin{array}{l}\text { neither agree nor } \\
\text { disagree }\end{array}$ & disagree & $\begin{array}{l}\text { strongly } \\
\text { disagree }\end{array}$ \\
\hline 11 & $\begin{array}{l}\text { I would like a career that } \\
\text { involves knowing a lot of } \\
\text { science. }\end{array}$ & $\begin{array}{l}\text { strongly } \\
\text { agree }\end{array}$ & agree & $\begin{array}{l}\text { neither agree nor } \\
\text { disagree }\end{array}$ & disagree & $\begin{array}{l}\text { strongly } \\
\text { disagree }\end{array}$ \\
\hline 12 & $\begin{array}{l}\text { I would like a career as an } \\
\text { engineer. }\end{array}$ & $\begin{array}{l}\text { strongly } \\
\text { agree }\end{array}$ & agree & $\begin{array}{l}\text { neither agree nor } \\
\text { disagree }\end{array}$ & disagree & $\begin{array}{l}\text { strongly } \\
\text { disagree }\end{array}$ \\
\hline 13 & $\begin{array}{l}\text { I would prefer my } \\
\text { teachers assess my } \\
\text { achievement through } \\
\text { portfolios rather than end } \\
\text { of the unit or chapter } \\
\text { tests. }\end{array}$ & $\begin{array}{l}\text { strongly } \\
\text { agree }\end{array}$ & agree & $\begin{array}{l}\text { neither agree nor } \\
\text { disagree }\end{array}$ & disagree & $\begin{array}{l}\text { strongly } \\
\text { disagree }\end{array}$ \\
\hline
\end{tabular}




\section{Student Survey (continued)}

\begin{tabular}{|c|c|c|c|c|c|c|}
\hline 14 & $\begin{array}{l}\text { I learn best when I find } \\
\text { information on my own } \\
\text { or self-teach. }\end{array}$ & $\begin{array}{l}\text { strongly } \\
\text { agree }\end{array}$ & agree & $\begin{array}{c}\text { neither agree nor } \\
\text { disagree }\end{array}$ & disagree & $\begin{array}{l}\text { strongly } \\
\text { disagree }\end{array}$ \\
\hline 15 & $\begin{array}{l}\text { I learn best when } \\
\text { information is presented } \\
\text { to me in a lecture-style } \\
\text { format. }\end{array}$ & $\begin{array}{l}\text { strongly } \\
\text { agree }\end{array}$ & agree & $\begin{array}{c}\text { neither agree nor } \\
\text { disagree }\end{array}$ & disagree & $\begin{array}{l}\text { strongly } \\
\text { disagree }\end{array}$ \\
\hline 16 & $\begin{array}{l}\text { I learn best through } \\
\text { hands-on activities. }\end{array}$ & $\begin{array}{l}\text { strongly } \\
\text { agree }\end{array}$ & agree & $\begin{array}{c}\text { neither agree nor } \\
\text { disagree }\end{array}$ & disagree & $\begin{array}{l}\text { strongly } \\
\text { disagree }\end{array}$ \\
\hline 17 & $\begin{array}{l}\text { I prefer learning by doing } \\
\text { projects. }\end{array}$ & $\begin{array}{l}\text { strongly } \\
\text { agree }\end{array}$ & agree & $\begin{array}{c}\text { neither agree nor } \\
\text { disagree }\end{array}$ & disagree & $\begin{array}{l}\text { strongly } \\
\text { disagree }\end{array}$ \\
\hline 18 & $\begin{array}{l}\text { I prefer learning by doing } \\
\text { group work. }\end{array}$ & $\begin{array}{l}\text { strongly } \\
\text { agree }\end{array}$ & agree & $\begin{array}{l}\text { neither agree nor } \\
\text { disagree }\end{array}$ & disagree & $\begin{array}{l}\text { strongly } \\
\text { disagree }\end{array}$ \\
\hline 19 & $\begin{array}{l}\text { I prefer learning by doing } \\
\text { book work. }\end{array}$ & $\begin{array}{l}\text { strongly } \\
\text { agree }\end{array}$ & agree & $\begin{array}{c}\text { neither agree nor } \\
\text { disagree }\end{array}$ & disagree & $\begin{array}{l}\text { strongly } \\
\text { disagree }\end{array}$ \\
\hline 20 & $\begin{array}{l}\text { I prefer learning through } \\
\text { lab experiences. }\end{array}$ & $\begin{array}{l}\text { strongly } \\
\text { agree }\end{array}$ & agree & $\begin{array}{l}\text { neither agree nor } \\
\text { disagree }\end{array}$ & disagree & $\begin{array}{l}\text { strongly } \\
\text { disagree }\end{array}$ \\
\hline
\end{tabular}




\section{Appendix C}

\section{Student Questionnaire}


(This page deliberately blank) 


\section{Student Questionnaire}

Please provide your comments below pertaining to the bridge project. Use extra space on the back if needed.

The project included the engineering process, member testing, WestPoint Bridge Builder computer program, bridge building, and portfolio report.

Overall, how would you rate this project?

$\begin{array}{llllll}\text { Rate the project } & 1 & 2 & 3 & 4 & 5\end{array}$

Terrible Great

Please describe what you liked most about the project and give specific details.

Please describe what you liked least about the project and give specific details.

Do you prefer a final test assessment like a chapter test or a final portfolio assessment? Please explain.

During the project, your team worked as an engineering firm that was bidding on a job. Do you have a better understanding of what an engineer does after doing this project? Please comment on what you believe an engineer does as an occupation. 
(This page deliberately blank.) 


\section{Appendix D \\ Lesson Plans}


(This page deliberately blank.) 
of a Bridge

Objectives:

- TLW calculate forces from assigned problems.

- TLW identify contact and field forces.

a TLW identify parts of a truss bridge.

Preparation:

口 Print copies of Need Statement

口 Print copies of Portfolio Rubric

- Overhead of The Engineering Process

- Split students into groups of 3.

口 PowerPoint ${ }^{\circledR}$ presentation: File Folders at Their Best

Instruction:

a Begin with Need Statement handout. Students will have in mind what the longterm goal is for the project.

$\circ$ Use Knight's Engineering Process to remind students the steps that will be taken through this project.

- Traditional lecture-style format will be used to teach contact and field forces and how to calculate them.

- Used Power Point as aid for instruction on bridge parts (Part One)

๑ Homework 4A 1-4, 4B 1-4

\section{References}

Ressler, S. J., P.E., Ph.D. (2002). Chapters 1, 2, 4, 5. In Designing and Building File-

Folder Bridges (pp. 1-1-2-28, 4-1-5-24). West Point, NY: Author.

Serway, R. A., \& Faughn, J. S. Holt Physics, pp. 124-157, 2002, Austin: Holt, Rinehart and Winston. 
(This page deliberately blank) 


\section{Powepoint ${ }^{\circledR}$ Presentation}

Slide 1

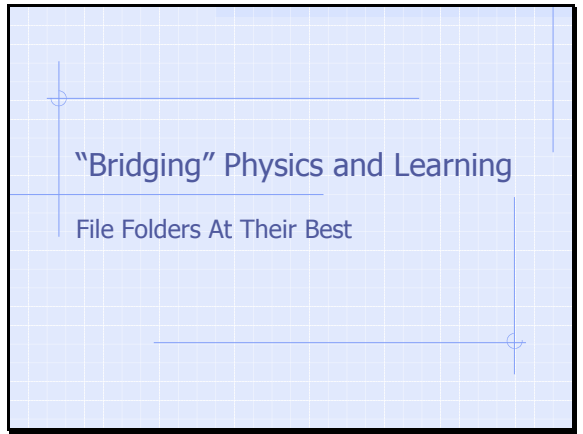

Slide 2

\section{Objectives}

$\checkmark$ Explain what a truss is

- Identify the major components of a bridge

and different types of truss bridges.

Explain the structural engineering concepts:

force, load, reaction, equilibrium, tension,

compression, and strength

- Explain how a truss bridge works-how each

individual component contributes to the

ability of the entire structure to carry a load.

Slide 3

Parts of a bridge

\section{$\rightarrow$ Truss}

- Made of diagonals,

verticals, top and

bottom chords

MVINA

$\downarrow$ Pin, Gusset Plate

$\downarrow$ Abutment 
Slide 4

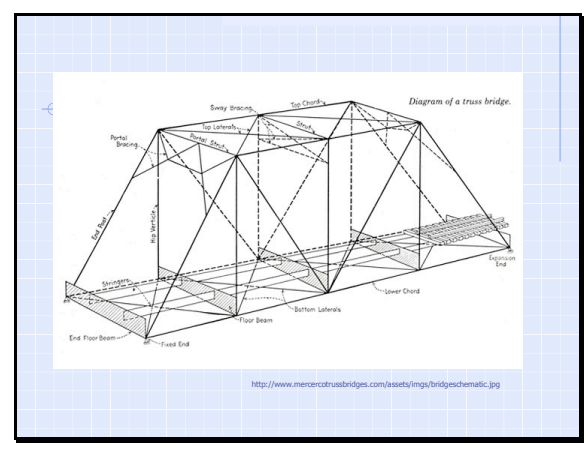

Slide 5

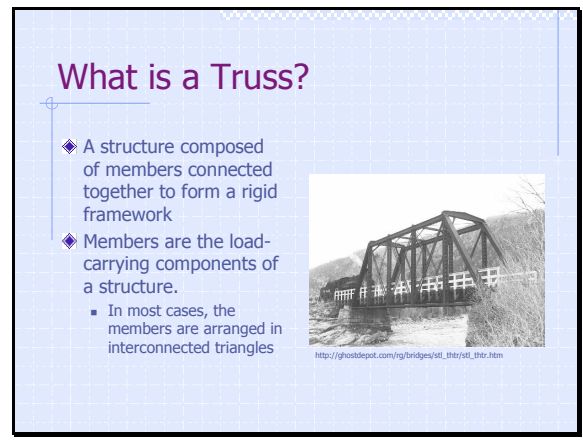

Slide 6

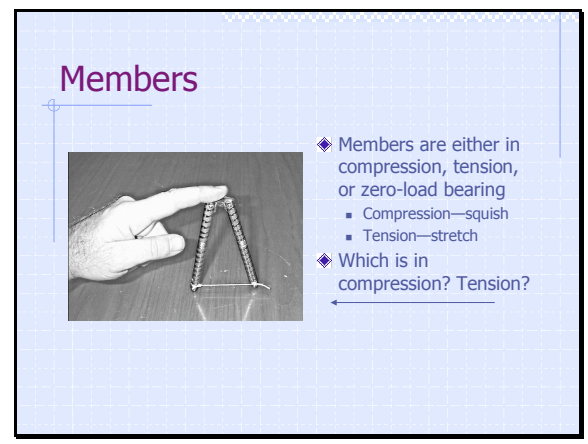


Slide 7

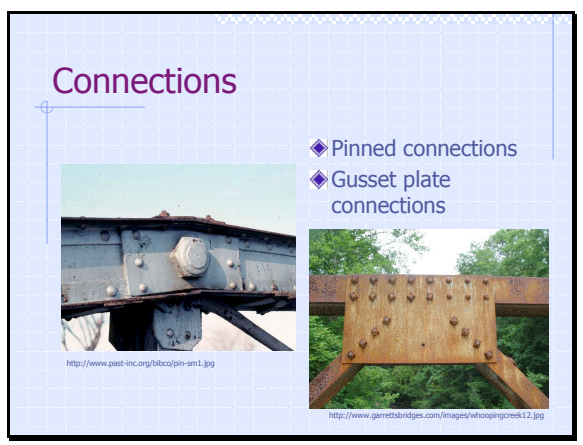

Slide 8

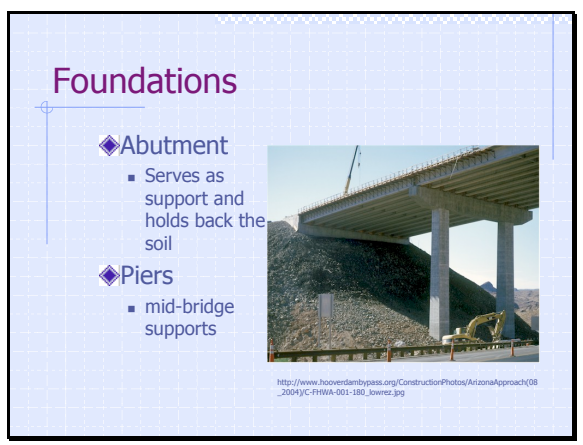

Slide 9

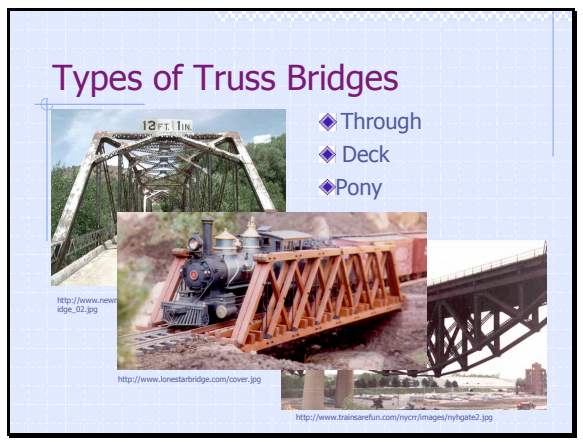


Slide 10

Carrying the Load

- Force-push or pull

- Forces will be represented by VECTORSmagnitude and direction

- Loads-Force applied to the structure

- What type of loads are bridges subjected to?

Slide 11

Carrying the Load

What is Newton's First Law?

What does Newton's First Law have to do with

a bridge?

- Equal and opposite REACTIONS

- Supports-points where the structure is physically in

contact with surroundings

- Where are supports located on a bridge?

- Equilibrium-the bridge will be in equilibrium because the total upward force equals the total downward force

Slide 12

Member Forces

- External forces

- Occur at the support when external

loads are applied

- Examples?

- Internal member forces are

developed within each structural

member

- Internal member forces are either in

tension or compression when a load is

applied to the member 
Slide 13

What is strength?

- Strength-The maximum internal force the component can experience before the structure fails.

- Failure occurs when the internal force becomes larger than its strength

Slide 14

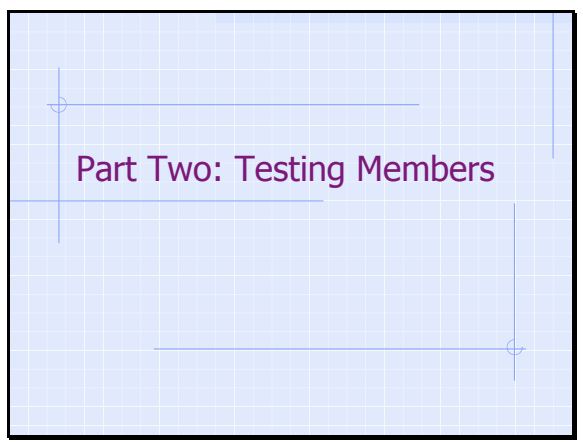

Slide 15

Activity 1: Testing the Strength of Structural Members

- Objectives

- Calculate the cross-sectional area of a structural

member.

- Describe the yielding, rupture, and buckling failure

modes.

- Explain the factors that affect the tensile strength

and compressive strength of a structural member.

- Determine the strength of structural members

. Explain the prinentation.

- Explain the principle of the lever and apply this

- Use a computer spreadsheet to analyze and graph experimental data 
Slide 16

Testing the Strength

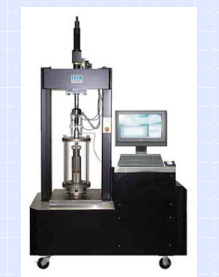

- Tensile Strength-the maximum tension force

a member can hold

$\checkmark$ Compressive Strengthmax compression force

a member can hold

before it fails

$\downarrow$ If we had the money..

(

Slide 17

Elastic vs. Plastic

$\checkmark$ Elastic-material returns to predeformation state

$\downarrow$ Plastic-material undergoes permanent

elongation after deformation

$\diamond$ Examples

- Rubber Band

- Polyethylene

Slide 18

Testing Tensile Strength

$\checkmark$ We could determine the load and deformation of the object

- Deformation-the increase in the length of the member as it is stretched

$\diamond$ Ductility is our friend

- Ductility-undergoes large plastic

deformation after yielding

- Yielding-undergoes large deformations with little change in load 
Slide 19

Testing Tensile Strength

$\checkmark$ Depends on:

- Cross-sectional area

- Type of material the member is made of

$\checkmark$ Does NOT depend on:

- Length of member

- Shape of cross-section

Slide 20

Testing Compressive Strength

- Load till it buckles

- Member bends in the direction perpendicular to the force applied

- Depends on

- Length

- Shape of cross-section

- Cross-sectional area

- Material

What's the difference in length?

- Rulers

Slide 21

To test strength...

$\diamond$ We will use a fulcrum and lever

- Lever-bar that rotates on a pivot

- Fulcrum-the pivot

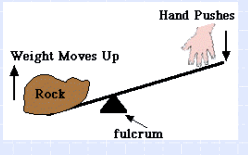


Slide 22

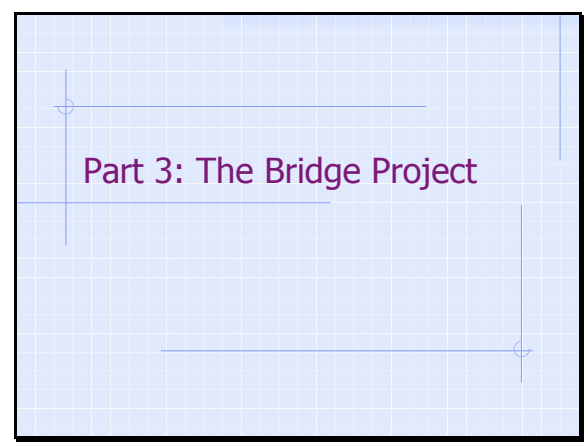

Slide 23

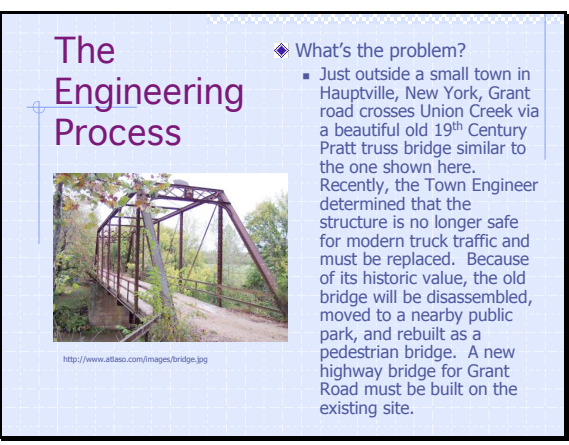

Slide 24

Step 1:

- Choose a bridge

structure 
Slide 25

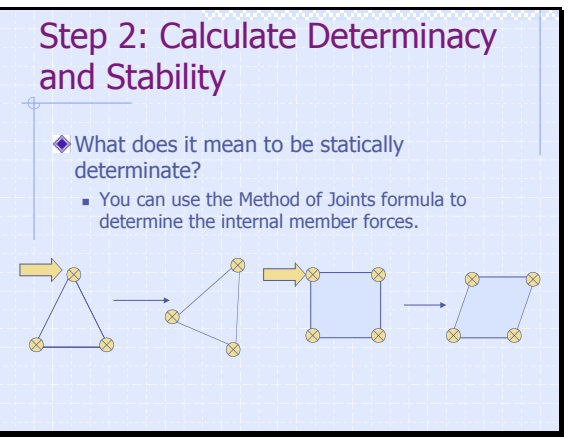

Slide 26

Calculate Determinant Bridges

- $\mathrm{m}=$ members

$j=$ joints

$-m+3$ is the number of unknowns

$\downarrow 2 \mathrm{j}$ is the number of joints

$\downarrow$ Example Bridge

- $m=23$

$\Delta$ When $\mathbf{m}+\mathbf{3}=\mathbf{2} \mathbf{j}$ we can say our bridge

is stable and determinate

$23+3=2(13)$

Slide 27

\begin{tabular}{|l|} 
Requirements \\
Drawings (to scale!!!) \\
-1 Elevation view-shows side of the bridge \\
-1 Top view \\
-1 Side view \\
One bridge \\
Calculations \\
- Determinant and stability \\
- Member forces \\
\hline
\end{tabular}


Slide 28

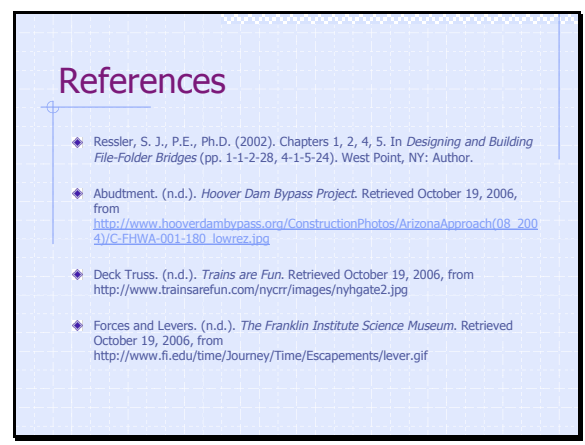

Slide 29

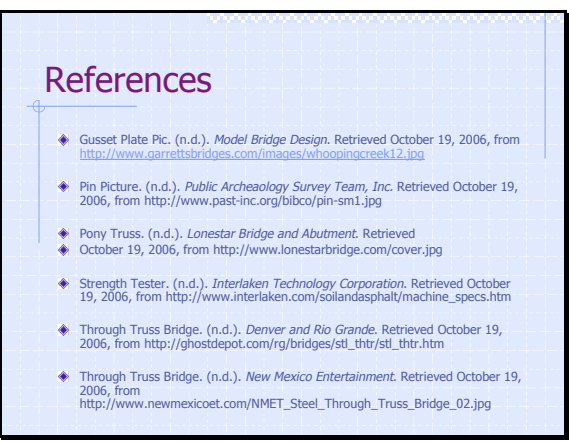

Slide 30

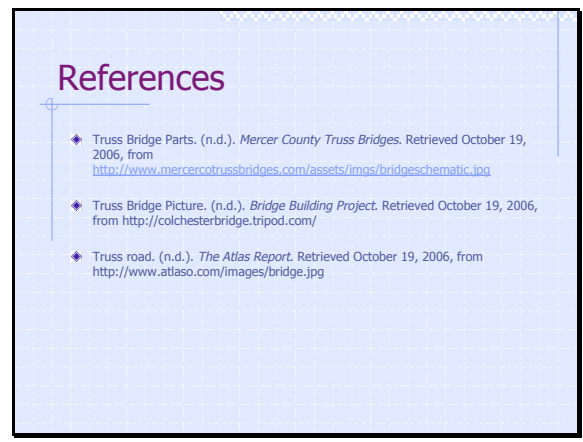




\section{The Need Statement}

The Need: Recently a tractor-trailer truck lost its breaks while driving on Grant Road. The driver lost control of the vehicle, and it collided with one of the end posts on the west end of the Grant Road Bridge. Fortunately, no one was hurt; but the bridge was damaged beyond repair. Grand Road is now closed, and the Town of Hauptville has initiated a project to replace the structure as quickly as possible. Design Requriements: The Town of Hauptville is the owner for this project. On behalf of the owner, the Town Engineer is looking to hire a new engineering company to contract the bridge. The engineers meet with the Town Council to work out the functional and aesthetic requirements for the new structure. At the meeting the Mayor says, "I don't want another bridge failure in my town. I want you to ensure that this new bridge is not as vulnerable to a vehicular collision as the old one was." The President of the Town Council adds, "We didn't plan on having to replace a bridge when we developed this year's budget. The cost of this project must be kept as low as possible." Another member of the Town Council adds, "The residents of Hauptville are very upset about the closure of Grant Road. We need to get this project completed as soon as possible." A member of the Hauptville Historical Society says, "I know money is tight. But it would be a terrible mistake to build an ugly bridge, just to save some money. We at the Historical Society think it's important to the preserve the historic character of the town so, if possible, we'd like the new bridge to be a truss." Finally, the Town Engineer adds his own input: "I am still very concerned with the ever-increasing number of heavy trucks using Grant Road. To give us an added margin of safety, 
I'd like the new structure to be designed for a $20 \%$ higher vehicular loading than the AASHTO bridge design code requires." Based on this input, as well as data gathered from a thorough investigation of the project site, the Town Engineer develop the following design requirements:

- The replacement bridge will be constructed on the existing abutments, which are 24 meters apart. [Our model is 1/40 scale and will have a span of 60 centimeters.]

- Like the previous bridge, the new structure will carry two lanes of traffic. However, the width of the deck will be increased by $20 \%$ to provide more space for larger vehicles. [Our model bridge will have a roadway width of 11 centimeters - 2 centimeters wider than the first Grant Bridge]

- The bridge will be designed for a vehicular loading $20 \%$ larger than that required by the AASHTO bridge design code. [Our model bridge will be designed for a "traffic load" consisting of a 6 kilogram mass placed on the structure at mid-span; the first Grant Road Bridge model was designed for only 5 kilograms.]

- The bridge will be made of steel. [Our model will use cardboard from standard manila file folders.]

- Because of the limited project budget, the cost of the new bridge must be kept to a minimum.

- To get the bridge into service as quickly as possible, design-build project delivery will be used for this project.

(Ressler, 2002, p 5-5) 


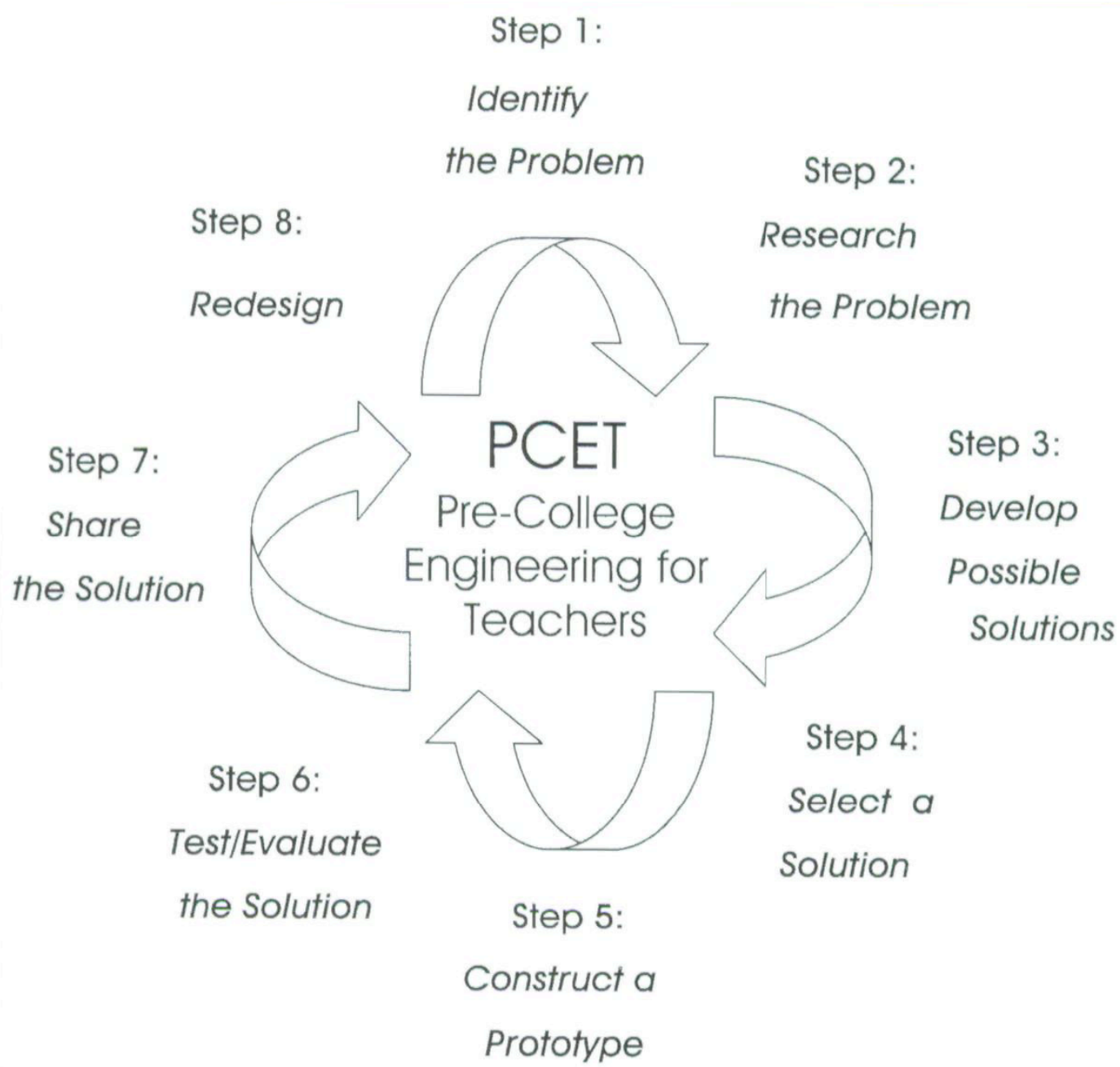

The engineering process as presented by Knight et al, 2006. 
(This page deliberately blank.) 


\section{Day Three -Compression and Tension Members in a Bridge}

Objectives:

․ TLW identify the difference between compression and tension members

a TLW identify contact and field forces in the bridge

- TLW identify parts of a truss bridge.

Preparation:

口 Copies of Ressler's Activity 2

- Demonstration: Nutcracker with rubber band connecting the two legs at the bottom.

- Demonstration: Two plastic rulers - one 12 inches and one approximately 2 inches long

口 Demonstration: Two empty paper towel roles

口 PowerPoint ${ }^{\circledR}$ presentation: File Folders at Their Best: Part 2

- Build a test machine. Found in Appendix C of Ressler (2002).

Instruction:

- Correct Homework from previous day.

口 Demonstration 1: Tension members

○ Stand the nutcracker on the ends of the legs.

○ Push on joint of nutcracker

- Rubber band will stretch to show a tension member

- Demonstration 2: Compression vs. length

○ Stand 12-inch ruler on end.

- Put hand on top of ruler and push down

- Repeat with short ruler

- Note how the long ruler will bow in the middle and the short ruler will not.

a Demonstration 3: Hollow vs. solid

○ A few days prior, cut through one paper towel role and set a heavy book on top of it to flatten it out

- Stand the uncut paper towel role on end and push on the end.

- Stand the cut paper towel role on end and push on end.

- Note how the tube does not bend while the flat tube does.

a Used Power Point as aid for instruction on bridge parts (Part Two)

- Discuss the requirements from Activity 2 for the portfolio.

- Show students how to use Testing Machine to test compression and tension members.

Checkpoint

- Students should read through Activity 2.

- Groups should write out a prediction for the relationship between compression and tension members and length and width of the members and the amount of 
sand it will hold before failure. This is recorded as a homework grade and will be included in the portfolio per rubric requirements.

\section{References}

Ressler, S. J., P.E., Ph.D. (2002). Chapters 1, 2, 4, 5. In Designing and Building FileFolder Bridges (pp. 1-1-2-28, 4-1-5-24). West Point, NY.

Serway, R. A., \& Faughn, J. S. Holt Physics, pp. 124-157, 2002, Austin: Holt, Rinehart and Winston. 


\section{Day Four and Five-Build and Test Structural Members in a Bridge}

Objectives:

a TLW construct compression and tension members from file folders

a TLW test the strength of members

a TLW test their own dimensions

Preparation:

- Copies of Ressler's Activity 2

- Sand, two buckets, three testing machines, 20 file folders, razor blades, wood glue, rubber cement, scrap booking paper cutter, mechanical pencils, ballpoint pens, and rulers.

Student Activity:

- Checkpoint: Students should turn in their predictions for Activity 2.

- Using a mechanical pencil with the lead in should be used to score the lines where the compression members will be folded. This will create a straight fold and make the cross-section of the compression member uniform.

- Students should use caution when using razor blades. A scrap booking paper cutter is much safer and faster for cutting.

- Students should make two compression and two tension members whose dimensions are not found in Ressler's requirements. These members should be made significantly different from the other members.

- Students should record data in table.

- Aid students using the Testing Machine.

\section{References}

Ressler, S. J., P.E., Ph.D. (2002). Chapters 1, 2, 4, 5. In Designing and Building FileFolder Bridges (pp. 1-1-2-28, 4-1-5-24). West Point, NY. 


\section{Day Six and Seven-Collaborate Experimental Data}

Objectives:

a $\quad$ TLW create data tables using Microsoft Excel ${ }^{\circledR}$

- TLW create graphs using Microsoft Excel ${ }^{\circledR}$

- TLW analyze data and compare it to accepted values

Preparation:

口 Copies of Ressler's Activity 2

口 Data projector to help guide students through Excel ${ }^{\circledR}$

Student Activity:

- Students will insert their experimental results into a worksheet and create a scatter plot from the data.

- Students will collaborate data from the class results.

- Students will analyze their data and compare it to the class data and the expected results.

․ This will be included in the portfolio.

- Any remaining time and be used to show students how to open and use West Point Bridge Program.

\section{References}

Ressler, S. J., P.E., Ph.D. (2002). Chapters 1, 2, 4, 5. In Designing and Building FileFolder Bridges (pp. 1-1-2-28, 4-1-5-24). West Point, NY.

West Point Bridge Designer 2007 (Version 9.0.0) [Computer software]. (n.d.). Retrieved from http://bridgecontest.usma.edu/download2006.htm 


\section{Day Eight and Nine-Bridge Design}

\section{Objectives:}

a TLW use West Point Bridge Designer Software to design bridge.

- TLW will design a determinant bridge.

- TLW observe the effects of changing the widths and lengths of compression and tension members in the bridge.

\section{Preparation:}

- Download program in advance of class date.

- Data projector will be useful to help answer questions from students.

口 Refer back to PowerPoint ${ }^{\circledR}$ notes to show students determinacy formula.

\section{Student Activity:}

- Students will use West Point Bridge Design to design a truss bridge.

\section{Checkpoint:}

- Students must turn in their computer-generated bridge. This is recorded as a homework grade and will not necessarily be included in the rubric as the teams may modify their bridge after assessing the distribution of the forces.

\section{Reference}

West Point Bridge Designer 2007 (Version 9.0.0) [Computer software]. (n.d.). Retrieved from http://bridgecontest.usma.edu/download2006.htm. 


\section{Day Ten and Eleven-Calculating Forces in a Bridge}

\section{Objectives:}

a TLW use trigonometry to determine the component forces in a vector.

a TLW use the method of joints to determine the forces within their bridge's members.

\section{Preparation:}

- Protractors will be needed to measure the angles between members of the bridges.

a Copy Part one of Learning Activity 3: Analyze and Evaluate a Truss

\section{Instruction:}

- Students will need to be reminded of component vectors from previous lessons.

- Students will need to be reminded of action/reaction forces that will be applied to the bridge.

- When a force is applied to the top of the bridge, the ground will push back with the same amount of force.

\section{Student Activity:}

- Students will measure out the angles in their bridges.

- Starting with the joint that will be meeting the ground, students will start to calculate the forces within each member.

a Using the method of joints, students will "cut" through the members of the joint to make it look like vectors originating from the joint.

\section{Checkpoint:}

a Students will turn in their math work for their bridges on day twelve.

- This will count as a homework grade. A final clean copy will be included in the portfolio.

- Students will predict where their bridge will fail. This will count as a homework grade and will be included in the portfolio.

\section{Reference}

Ressler, S. J., P.E., Ph.D. (2002). Chapters 1, 2, 4, 5. In Designing and Building File-

Folder Bridges (pp. 1-1-2-28, 4-1-5-24). West Point, NY.

\section{Days Twelve, Thirteen, and Fourteen-Apply for Permits and Construction}

Objectives: 
- TLW get bridge approved.

- TLW begin construction of bridges.

Preparation:

口 Copies of building instructions from Activity 1.

- Copies of directions (which includes the need statement) from Activity 5.

- Sand, two buckets, three testing machines, 20 file folders, razor blades, wood glue, rubber cement, scrap booking paper cutter, mechanical pencils, ballpoint pens, and rulers.

Instruction:

- Hand back calculations from previous day.

- Approve bridge by checking students' determinacy calculations, force calculations, prediction of failure, and sketch.

a Using a mechanical pencil with the lead in should be used to score the lines where the compression members will be folded. This will create a straight fold and make the cross-section of the compression member uniform.

- Students should use caution when using razor blades. A scrap booking paper cutter is much safer and faster for cutting.

- Observe and aid groups when necessary.

Checkpoint:

a Bridges are due on returning school day.

○ Students were given three school days and two weekend days to complete their bridge construction.

\section{Reference}

Ressler, S. J., P.E., Ph.D. (2002). Chapters 1, 2, 4, 5. In Designing and Building FileFolder Bridges (pp. 1-1-2-28, 4-1-5-24). West Point, NY. 


\section{Day Fifteen-Bridge Testing}

\section{Objectives:}

- TLW test bridges

\section{Preparation:}

- Pennies to make sure weight is evenly distributed on the bridge and applied only to the designated joints and for the bridge to rest on the table.

a Print copies of bridge score sheet

a Book to place on pennies.

a Bucket with sand. When added together, the book, bucket and sand will equal $59 \mathrm{~N}$.

- Sand, scale, and two buckets.

\section{Student Activity:}

- Students will set up the pennies, book and bucket of sand on their bridges.

a The bridges must hold the $59 \mathrm{~N}$ for 30 seconds without failure.

- After all bridges are tested, students will have the option of testing their bridges to failure.

a Any remaining time will be spent discussing questions about the portfolio.

\section{Reference}

Ressler, S. J., P.E., Ph.D. (2002). Chapters 1, 2, 4, 5. In Designing and Building FileFolder Bridges (pp. 1-1-2-28, 4-1-5-24). West Point, NY. 


\section{Bridge Scoring Rubric}

Group Name

\begin{tabular}{|c|c|c|c|c|}
\hline Score component & Joints & $\begin{array}{c}\text { Hollow } \\
\text { Members }\end{array}$ & $\begin{array}{c}\text { Solid } \\
\text { Members }\end{array}$ & Total \\
\hline
\end{tabular}

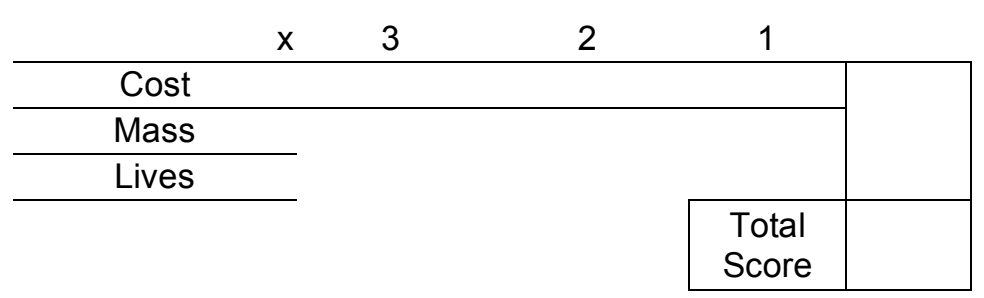

\begin{tabular}{|c|c|c|}
\multicolumn{1}{c}{} & \multicolumn{1}{c}{$\begin{array}{c}\text { Points } \\
\text { Earned }\end{array}$} & $\begin{array}{c}\text { Points } \\
\text { Possible }\end{array}$ \\
\hline $\begin{array}{c}\text { Determinant and } \\
\text { Stable }\end{array}$ & & 3 \\
\hline
\end{tabular}

\begin{tabular}{|c|c|c|c|}
\cline { 2 - 4 } \multicolumn{1}{c|}{} & Height & Length & Roadway \\
\hline Dimensions & & & \\
\hline $\begin{array}{c}\text { Requirement }(+/- \\
1 \mathrm{~cm})\end{array}$ & $8 \mathrm{~cm}$ & $60 \mathrm{~cm}$ & $11 \mathrm{~cm}$ \\
\hline
\end{tabular}

\begin{tabular}{|c|c|c|}
\cline { 1 - 2 } $\begin{array}{c}\text { Bridge Grading } \\
\text { Rubric }\end{array}$ & \multicolumn{2}{|l}{} \\
\hline Component & $\begin{array}{c}\text { Points } \\
\text { Earned }\end{array}$ & $\begin{array}{c}\text { Points } \\
\text { Possible }\end{array}$ \\
\hline $\begin{array}{c}\text { Stable and } \\
\text { Determinant }\end{array}$ & 1 \\
\hline $\begin{array}{c}\text { Holds } 6 \mathrm{~kg} \text { for } 30 \\
\text { seconds }\end{array}$ & & 2 \\
\hline $\begin{array}{c}\text { Lowest Bridge } \\
\text { Score not }=0\end{array}$ & & 2 \\
\hline Dimensions & & 11 \\
\hline Built and On Time & & \\
\hline
\end{tabular}

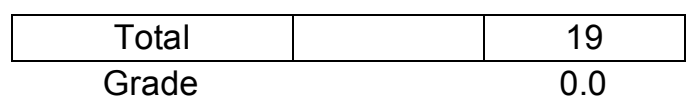


(This page deliberately blank) 


\section{Day Sixteen-Portfolio Work}

\section{Objectives:}

․ TLW work with teammates to complete portfolio.

\section{Instruction:}

- Class discussion will be held for questions pertaining to the portfolio requirements.

a Walk around from group to group, observe students working, and answer questions students have about their projects.

\section{Student Activity:}

- Students will have the opportunity to work with teammates to complete the portfolio.

\section{Reference}

Ressler, S. J., P.E., Ph.D. (2002). Chapters 1, 2, 4, 5. In Designing and Building FileFolder Bridges (pp. 1-1-2-28, 4-1-5-24). West Point, NY. 


\section{Day Twenty-one-Portfolios Due}

\section{Objectives:}

a Teams will turn in their portfolios.

- Students evaluate their group members.

- Students complete post-survey.

口 Students complete student questionnaire.

\section{Student Activities:}

- If time remains, students may view other groups' work. 
Appendix E

Raw Data 
(This page deliberately blank) 
Raw Data for Table 6: Pre-survey Statements Assessing Attitude Toward Science and Careers

\begin{tabular}{|c|c|c|c|c|c|c|c|c|c|}
\hline & $\begin{array}{c}\text { Stmt } \\
\text { Number }\end{array}$ & $\begin{array}{l}\text { strongly } \\
\text { agree }\end{array}$ & agree & $\begin{array}{l}\text { neither } \\
\text { agree nor } \\
\text { disagree }\end{array}$ & disagree & $\begin{array}{l}\text { strongly } \\
\text { disagree }\end{array}$ & $\mathrm{N}$ & Mean & SD \\
\hline \multirow[t]{9}{*}{ Science } & 1 & 5 & 15 & 2 & 1 & 0 & 23 & 3.83 & 0.72 \\
\hline & 2 & 3 & 11 & 5 & 4 & 0 & 23 & 3.35 & 0.95 \\
\hline & 3 & 5 & 17 & 0 & 1 & 0 & 23 & 3.91 & 0.65 \\
\hline & 4 & 1 & 8 & 8 & 5 & 1 & 23 & 3.13 & 0.95 \\
\hline & 5 & 5 & 15 & 3 & 0 & 0 & 23 & 4.09 & 0.58 \\
\hline & 6 & 1 & 10 & 5 & 5 & 2 & 23 & 3.13 & 1.08 \\
\hline & 7 & 10 & 6 & 5 & 2 & 0 & 23 & 4.04 & 0.99 \\
\hline & 8 & 15 & 5 & 3 & 0 & 0 & 23 & 4.52 & 0.71 \\
\hline & & & & & & & Average & 3.75 & 0.83 \\
\hline \multirow[t]{6}{*}{ Careers } & 9 & 8 & 14 & 1 & 0 & 0 & 23 & 4.3 & 0.54 \\
\hline & 10 & 6 & 13 & 4 & 0 & 0 & 23 & 4.08 & 0.65 \\
\hline & 11 & 4 & 12 & 3 & 4 & 0 & 23 & 3.7 & 0.95 \\
\hline & 12 & 2 & 3 & 4 & 9 & 5 & 23 & 2.48 & 1.21 \\
\hline & & & & & & & Average & 3.64 & 0.84 \\
\hline & & & & & & & $\begin{array}{l}\text { Overall } \\
\text { average }\end{array}$ & 3.71 & 0.83 \\
\hline
\end{tabular}

Raw Data for Table 7: Pre-survey Statements Assessing Preferences of Students

\begin{tabular}{ccccccccc}
\hline $\begin{array}{c}\text { Stmt } \\
\text { Number }\end{array}$ & $\begin{array}{c}\text { strongly } \\
\text { agree }\end{array}$ & agree & $\begin{array}{c}\text { neither } \\
\text { agree nor } \\
\text { disagree }\end{array}$ & disagree & $\begin{array}{c}\text { strongly } \\
\text { disagree }\end{array}$ & N & Mean & SD \\
\hline 13 & 2 & 12 & 4 & 3 & 2 & 23 & 3.39 & 1.09 \\
14 & 3 & 7 & 1 & 8 & 4 & 23 & 2.87 & 1.36 \\
15 & 5 & 5 & 6 & 7 & 0 & 23 & 3.34 & 1.12 \\
16 & 0 & 6 & 11 & 4 & 2 & 23 & 2.91 & 0.88 \\
17 & 3 & 12 & 1 & 5 & 2 & 23 & 3.39 & 1.2 \\
18 & 7 & 8 & 1 & 1 & 6 & 23 & 3.39 & 1.58 \\
19 & 2 & 4 & 5 & 11 & 1 & 23 & 2.78 & 1.06 \\
20 & 5 & 9 & 3 & 4 & 2 & 23 & 3.48 & 1.25 \\
& & & & & & & & \\
Average & $\mathbf{3 . 1 9}$ & $\mathbf{1 . 1 9}$ \\
\hline
\end{tabular}

Raw Data for Table 8: Post-survey Change in Attitude of Students 


\begin{tabular}{ccccccccccc}
\hline $\begin{array}{c}\text { Stmt } \\
\text { Number }\end{array}$ & $\begin{array}{c}\text { strongly } \\
\text { agree }\end{array}$ & $\begin{array}{c}\text { agree } \\
\text { agree nor } \\
\text { disagree }\end{array}$ & $\begin{array}{c}\text { neither } \\
\text { agragree }\end{array}$ & $\begin{array}{c}\text { strongly } \\
\text { disagree }\end{array}$ & N & Mean & SD & Difference & $\begin{array}{c}\text { Effect } \\
\text { Size }\end{array}$ \\
\hline 1 & 8 & 12 & 1 & 2 & 0 & 23 & 3.91 & 0.88 & -0.08 & 0.11 \\
2 & 3 & 12 & 6 & 2 & 0 & 23 & 3.47 & 0.08 & -0.12 & 0.13 \\
3 & 5 & 16 & 0 & 2 & 0 & 23 & 3.83 & 0.78 & 0.08 & -0.12 \\
4 & 0 & 7 & 6 & 7 & 3 & 23 & 2.74 & 1.03 & 0.39 & -0.41 \\
5 & 5 & 16 & 2 & 0 & 0 & 23 & 4.13 & 0.53 & -0.04 & 0.07 \\
6 & 2 & 7 & 4 & 5 & 5 & 23 & 2.83 & 1.31 & 0.3 & -0.28 \\
7 & 9 & 7 & 6 & 1 & 0 & 23 & 4.04 & 0.91 & 0 & 0 \\
8 & 15 & 6 & 2 & 0 & 0 & 23 & 4.57 & 0.64 & -0.05 & 0.07 \\
& & & & & & Average & $\mathbf{3 . 6 9}$ & $\mathbf{0 . 7 7}$ & $\mathbf{0 . 0 6}$ & $\mathbf{- 0 . 0 5}$ \\
9 & 7 & 14 & 2 & 0 & 0 & 23 & 4.22 & 0.59 & 0.08 & -0.15 \\
10 & 8 & 12 & 2 & 1 & 0 & 23 & 4.17 & 0.76 & -0.09 & 0.14 \\
11 & 5 & 11 & 5 & 1 & 1 & 23 & 3.78 & 0.98 & -0.08 & 0.08 \\
12 & 2 & 3 & 4 & 7 & 7 & 23 & 2.39 & 1.28 & 0.09 & -0.07 \\
& & & & & & Average & $\mathbf{3 . 4 5}$ & $\mathbf{1 . 0 1}$ & $\mathbf{- 0 . 0 3}$ & $\mathbf{0 . 0 5}$ \\
\hline
\end{tabular}

Raw Data for Table 9: Post-survey Change in Preference of Students

\begin{tabular}{ccccccccccc}
\hline $\begin{array}{c}\text { Stmt } \\
\text { Number }\end{array}$ & $\begin{array}{c}\text { strongly } \\
\text { agree }\end{array}$ & $\begin{array}{c}\text { agree } \\
\text { agree nor } \\
\text { disagree }\end{array}$ & $\begin{array}{c}\text { neither } \\
\text { aragree }\end{array}$ & $\begin{array}{c}\text { strongly } \\
\text { disagree }\end{array}$ & N & Mean & SD & Difference & $\begin{array}{c}\text { Effect } \\
\text { Size }\end{array}$ \\
\hline 13 & 4 & 10 & 4 & 3 & 2 & 23 & 3.48 & 1.17 & -0.09 & 0.08 \\
14 & 2 & 6 & 9 & 5 & 1 & 23 & 3.13 & 0.99 & -0.26 & 0.19 \\
15 & 5 & 5 & 5 & 8 & 0 & 23 & 3.3 & 1.15 & 0.04 & -0.04 \\
16 & 1 & 8 & 8 & 4 & 2 & 23 & 3.08 & 1.02 & -0.17 & 0.19 \\
17 & 2 & 12 & 1 & 5 & 3 & 23 & 3.22 & 1.24 & 0.17 & -0.14 \\
18 & 1 & 13 & 4 & 2 & 3 & 23 & 3.3 & 1.12 & 0.09 & -0.06 \\
19 & 1 & 3 & 8 & 10 & 1 & 23 & 2.7 & 0.91 & 0.08 & -0.08 \\
20 & 0 & 10 & 2 & 8 & 3 & 23 & 2.83 & 1.13 & 0.65 & -0.52 \\
& & & & & & & & & & \\
Average & $\mathbf{3 . 0 8}$ & $\mathbf{1 . 0 8}$ & $\mathbf{0 . 0 9}$ & $\mathbf{- 0 . 0 6}$ \\
\hline
\end{tabular}

Raw Data for Table 10: Student Questionnaire Results From Project Ranking.

\begin{tabular}{cccccccc}
\hline $\begin{array}{c}1 \\
\text { Terrible }\end{array}$ & 2 & 3 & 4 & $\begin{array}{c}5 \\
\text { Great }\end{array}$ & N & Mean & SD \\
\hline 3 & 5 & 9 & 4 & 2 & 23 & 2.87 & 1.08 \\
\hline
\end{tabular}

